
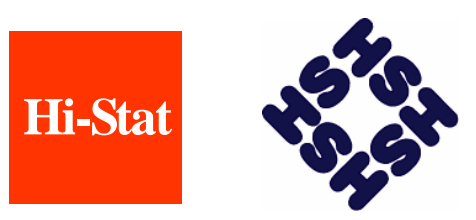

Discussion Paper Series

No.31

\title{
What Caused the Recent Surge of FDI into Japan?
}

\author{
Ralph Paprzycki
}

April 2004

\author{
Hitotsubashi University Research Unit \\ for Statistical Analysis in Social Sciences \\ A 21st-Century COE Program \\ Institute of Economic Research \\ Hitotsubashi University \\ Kunitachi, Tokyo, 186-8603 Japan \\ http://hi-stat.ier.hit-u.ac.jp/
}




\title{
What Caused the Recent Surge of FDI into Japan?
}

\author{
Ralph Paprzycki*
}

April 2004

\begin{abstract}
In recent years, foreign direct investment (FDI) in Japan has jumped to unprecedented levels. This paper examines the underlying reasons, looking at both the international factors - the global boom in FDI and mergers \& acquisitions (M\&A) during 1998-2000 - and domestic regulatory, structural and other changes. It is argued that while domestic changes created the necessary conditions for Japan to participate in the global M\&A boom, FDI inflows failed to develop a momentum of their own. Thus, rather than the result of a sudden transformation of the country into a major destination for global FDI flows, the recent surge in Japan was primarily driven by global trends.
\end{abstract}

*Correspondence: Ralph Paprzycki, Institute of Economic Research, Hitotsubashi University, Naka 2-1, Kunitachi, Tokyo 186-8603. E-mail: ralphp@ier.hit-u.ac.jp 


\section{Introduction}

Over the past few years, something extraordinary has been happening in Japan. Virtually closed to foreign business interests for much of the distant and even the more recent past, the country has, as of late, experienced a veritable boom in inflows of foreign direct investment (FDI): in the space of only five years, from 1998 to 2002, it attracted more such inflows than in the entire period before. ${ }^{1}$ What happened? Has there been a magical "Open Sesame," the unlocking of doors hitherto shut to foreign business, and the sudden discovery of untold hidden riches attracting treasure seekers far and wide? The answer is more prosaic, both in a figurative and in a literal sense.

The purpose of this paper is to take a closer look at this recent surge of FDI in Japan, to examine its causes and consider the likelihood of its being sustained. ${ }^{2}$ It will be shown that the reasons for the rapid growth in inward FDI flows is a combination of two coinciding events: the boom in FDI, and especially mergers and acquisitions (M\&A), that swept the globe in the 1990s; and domestic changes that created the necessary conditions for Japan to participate in this global boom. These changes were mainly triggered by the deterioration of the Japanese economy, which eroded many of the real or perceived informal barriers to FDI (such as high prices and cross-shareholdings), spurred the government into action to deregulate, produced distressed companies that were potential take-over targets, and led to a general shift in attitudes towards foreign investment in Japan - among both government officials and the public. In fact, after decades of obstructing the entry of foreign companies, the government is now actively seeking it. In January 2003, Prime Minister Koizumi announced the goal to double the stock of FDI in the country by 2008, and various measures to achieve this aim were subsequently introduced.

Whether this ambitious target can be achieved, though, is doubtful. It will be argued here that the recent surge in FDI into Japan to a great extent owes to worldwide trends and should therefore not be interpreted as a sign that the country has all of a sudden transformed itself into a magnet for global business. Domestic structural and other changes - rather than acting as a pull on FDI flows - have simply unlocked the door to the massive push of the M\&A boom worldwide. Latest figures indicate that FDI flows into Japan may indeed be developing a momentum of their own, but it is still too early to say.

\section{The boom in inward FDI}

Ever since the first Portuguese traders reached Japanese shores in the $16^{\text {th }}$ century, foreign businessmen have tried, and frequently failed, to gain access to the country's market. For most of the past 450 years, Japan's leaders have viewed the presence of foreign business interests as detrimental to national sovereignty and economic development. Consequently, with the exception of a few brief spells, foreign direct investment was severely restricted, if not banned outright.

\footnotetext{
${ }^{1}$ Calculated on a notification basis.

${ }^{2}$ This draft is part of a larger research project the author is working on in collaboration with K. Fukao, also of the Institute of Economic Research, Hitotsubashi University, that not only investigates the causes for the recent increase in FDI inflows, but more importantly, also examines the impact FDI is having on the Japanese economy.
} 
Even when most official controls on foreign direct investment were abolished in the 1970s, informal barriers or "structural impediments" remained. The result: FDI "flows" into Japan are probably more adequately described as a trickle. Throughout the 1970s and until the mid1980s, inward FDI never exceeded more than 1 billion US\$ in any given year and, on average, reached only about 450 million US\$ on a notification basis. ${ }^{3}$ Measured against these standards, FDI inflows did register a noticeable increase during the ten years that followed, gradually climbing to around 4 billion US\$ annually in the mid-1990s. However, to put these figures into perspective: at the end of 1995, the cumulative FDI stock in the second-largest economy in the world stood at a mere 33.5 billion US\$ or only slightly more than half the 57.1 billion US\$ recorded by Switzerland with a population one-eighteenth the size of Japan’s. ${ }^{4}$

During the late 1990s, however, foreign direct investment in Japan all of a sudden became headline news. Annual inflows accelerated markedly, jumping to 10.5 billion US\$ in 1998 and 28.3 billion US\$ in 2000 (see figure 1). The cumulative total from 1998 to 2002 together amounted to 97.0 billion US\$ - almost twice the 49.8 billion US\$ registered during the period 1970 to 1997. However, more than these figures, what commanded attention was the nature of this investment. For the first time, mergers and acquisitions (M\&A) were playing a significant role: in a string of high-profile deals, foreigners bought controlling shares in some of the country's largest and best-known companies. The value of so-called "out-in M\&As," where a foreign company acquires a stake in a domestic firm, jumped from an annual average of only 320 million US\$ during 1990-95 to more than 15 billion US\$ during 1999-2001 (see figure 2). M\&As traditionally are the most important form of foreign direct investment in developed economies and, as will be shown below, the rise in inward FDI is not only closely linked with, but essentially the result of, increased out-in M\&A activity.

Insert figures 1 and 2

The boom in foreign direct investment bound for Japan in recent years has been heavily concentrated in a small number of industries, mostly in the service sector (see table 1). Chief amongst them were the finance \& insurance and the telecommunications industries. Other important sectors were retail and wholesale trade, services, and, in the manufacturing sector, the machinery industry (led by the automotive sector). Together, these five industries accounted for more than four-fifth of all FDI inflows during 1996-2002. A considerable number of sectors hardly saw any foreign direct investment at all, including the food, textiles, rubber \& leather, and glass \& ceramics industries in the manufacturing sector and construction, transportation, and real estate in the non-manufacturing sector. The overall pattern thus is very much in line with the impression given by headline-grabbing deals such as the acquisition of Japan Telecom first by British Telecom and AT\&T and then Vodafone, the purchase of controlling stakes in Nissan and Mitsubishi Motors by Renault and DaimlerChrysler, and the dozens of deals in the financial sector, where companies from the U.S. and Europe have bought more than a dozen ailing Japanese insurance and other financial firms.

\footnotetext{
${ }^{3} 210$ million US\$ on a balance-of-payments basis. BOP and notification figures each have their own distinct advantages and disadvantages. BOP data tends to understate foreigners' investment position since it does not include funds raised within the host economy. In contrast, notification data tends to overstate foreigners' investment position, because it only registers foreigners' investment intentions without following up whether the investment in fact took place. Moreover, it does not count withdrawals. On the other hand, Japanese FDI data suffers from a host of other shortcomings such as the failure to include reinvested earning that understate the extent of foreign investment. For a detailed discussion of Japanese FDI data, see, for example, Feenstra (1999).

${ }^{4}$ Comparison on a BOP basis. Figures are from the UNCTAD World Investment Report 2003.
} 
Insert table 1

\section{International factors behind the surge in FDI in Japan}

In order to examine the factors behind the surge in foreign direct investment flows into Japan it is useful to distinguish between international and domestic factors. The latter will be addressed shortly. First, however, let us turn to the international background, i.e. the global boom in FDI flows, without which foreign investment in Japan would not have increased to the extent it did.

This global boom saw annual FDI outflows worldwide rise six-fold from around 200 billion US\$ in 1991 to a peak of 1,200 billion US\$ in the year 2000 (see figure 3). A number of political, economic, and technological factors contributed to this trend. Throughout the 1990s, countries around the world were liberalizing trade and investment regimes and, in many cases, competed to attract export-oriented FDI. At the same time, technical progress in areas such as transportation, logistics, and especially communication greatly facilitated the coordination of globally dispersed activities. What is more, economic liberalization and technical progress have interacted to create fiercely competitive global markets, forcing transnational corporations to invest in new markets and seek low-cost factors of production. Finally, the United States, home to the largest TNCs and the most important source of foreign direct investment, registered extraordinarily rapid economic growth throughout the decade, providing companies with the necessary financial resources to invest overseas.

Insert figure 3

In few other industries can the interplay of deregulation, technological change and intensifying global competition be seen as clearly as in the telecommunications sector. Still dominated by state monopolies at the beginning of the 1990s, following (partial) privatization, liberalization, and the rapid spread of mobile telephony the sector became the growth industry par excellence. By the end of the decade, a handful of companies were vying for global dominance and seeking a presence in each of the major markets. The quickest route to do so was to acquire a local incumbent, offering instant market access. The result of these dynamics: the value of annual cross-border M\&As in the telecommunications sector rose from around 3 billion US\$ in the early 1990s to a peak of 366 billion US\$ in 2000, and the share of the sector in total cross-border M\&As jumped from less than 5 percent to almost a third.

Other sectors where global cross-border M\&A activity accelerated considerably during the second half of the 1990s were, in the service sector, finance and trade and, in the manufacturing sector, the chemical, electrical machinery and motor vehicle industries. Economic deregulation, technical progress and the ensuing increase in competition played a central role in most of these sectors as well. Financial services, for example, formed part of the WTO agenda to liberalize international trade in services and have seen rapid increases in productivity thanks to the widespread introduction of information technology. These trends have combined to turn financial services into an increasingly global business. Cross-border M\&As in the sector rose from around 12-14 billion US\$ annually in the early 1990s to a peak of 184 billion US\$ in 2000. This growth was more or less in line with overall trends: the 
sector's share in total cross-border M\&As hovered at around 16-17 percent throughout most of the period.

Or to take a prominent example from the manufacturing sector: for the car industry, the 1990s were a decade of global consolidation. Worldwide excess capacity rose considerably throughout the decade, eroding the profitability of the weakest makers and culminating in a number of mega-mergers such as that between Germany's Daimler-Benz and Chrysler of the United States and Renault (France) and Nissan (Japan). Cross-border M\&As in this industry were below 5 billion US\$ a year for most of the decade, but then jumped to 51 billion US\$ in 1998. (Though subsequently dropping again, the 19 and 25 billion US\$ registered in 1999 and 2000 were still substantially above previous levels.)

The overall and sectoral trends described here are important because inward FDI flows and out-in M\&As in Japan form an almost perfect mirror-image of these global trends. At first sight, this is not a particularly deep insight: after all, the country is part of the world economy and any global trend would also affect Japan. However, in attempting to assess the reasons for the recent upsurge in FDI in Japan and considering its sustainability, it is essential to keep this global background in mind.

\section{Domestic factors}

While the global FDI/M\&A boom meant that huge sums of money were sloshing around the world economy, it is doubtful that much of this would have found its way to Japan had it not been for wide-ranging domestic changes that have made it much easier for foreign companies to invest in the country. These changes are the result of a mixture of different, intertwined developments. To some extent, the opening of the Japanese economy to foreign business simply represents a continuation of the gradual liberalization of foreign investment that was begun in the 1960s and broadened in the 1970s and 1980s. In addition, the prolonged recession which began in the early 1990s and from which the country has yet to recover triggered a number of reform measures aimed at making the economy more flexible. And finally, the ongoing malaise itself served as a catalyst for structural change. Although economic policy and structural change in Japan are often described as progressing at a snail's pace, cumulatively, these developments have led to quite a substantial transformation of the economy. What follows is a brief discussion of individual policy measures or economic trends and their import for foreign direct investment activity in Japan.

\section{Deregulation in the non-manufacturing sector}

Though Japan had liberalized FDI in most manufacturing sectors in the 1970s and 1980s, investment controls remained in a number of service industries. Often, such controls did not explicitly discriminate against foreigners. However, by restricting the entry of new firms, they effectively barred any foreign investment. A case in point is the Large Retail Store Law, which had been designed to protect smaller shops by restricting the activities of retail giants and forcing the latter to go through a time-consuming consultation and adjustment process. The law was revised in 1992 and again in 2000, when it was replaced by the Large Retail Store Location Law. While during the 1980s only a handful of foreign companies, mainly luxury goods makers, established retail outlets in Japan, both the number and range of retailers expanded considerably during the 1990s. 
Though certain restrictions remain until this day, another sector in which foreign direct investment jumped once some barriers had been removed is the telecommunications industry. First steps towards the liberalization of the market occurred following the (partial) privatization of Nippon Telegraph \& Telecom (NTT), the government monopoly, in 1985. In 1994, the Telecommunications Business Law was introduced, relating among other things to mobile phones which until then had been illegal in Japan, and in 1998, all restrictions on foreign investment in Type I carriers, except for KDD (Kokusai Denshin Denwa Ltd.) and NTT, were lifted. ${ }^{5}$ Moreover, in 1999, all barriers to foreign ownership in the cable TV business were abolished. Foreign telecommunications companies moved almost immediately to take advantage of these changes: in June 1999, Cable \& Wireless acquired International Digital Communications (IDC) in the first successful hostile takeover bid by a foreign company in Japan, while only a few months later, British Telecom and AT\&T jointly bought a 30 percent stake in Japan Telecom.

Another area in which deregulation was followed by inflows of foreign direct investment is the financial sector. Though few independent observers would really call it a "Big Bang" as Japanese officials are wont to do, the Financial System Reform Law enacted in 1998 removed regulatory obstacles separating different categories of financial institutions and made it possible to sell new types of financial product in Japan. Stock brokerage commissions were liberalized the following year. On their own, i.e. without the presence of a large number of ailing Japanese banks and insurance companies that were easy takeover targets, these steps probably would not have been sufficient to attract the amount of foreign investment in the sector actually observed. However, these measures do form the basis on which foreign firms can bring to bear their superior products, business know-how and organization in order to make such an investment (potentially) profitable.

While many of the regulations that were lifted in the 1990s did not explicitly discriminate against foreigners, they stifled competition and market entry more generally, no matter what the nationality of potential competitors. The removal of such regulations and the introduction of greater competition in these service sectors thus for the first time allowed foreign investors to participate in the Japanese market. However, this still would have been very difficult had it not been for the gradual weakening of more informal barriers that had compounded the problem of official regulation.

\section{Unwinding of cross-shareholdings}

Another barrier to foreign direct investment in Japan in the past has been the presence of the keiretsu. While it remains a mute point whether the corporate groups restricted foreign market access through oligopolistic business practices, what seems beyond dispute is that the substantial cross-shareholdings that keiretsu members engaged in severely restricted the supply of acquirable assets. ${ }^{6}$ And since M\&As have been the most important conduit for foreign direct investment developed economies, the lack of acquirable assets has been an important factor in restricting FDI in Japan. In fact, the extensive cross-shareholdings that the keiretsu are famous for and that have been one of their defining features arose just at a time

\footnotetext{
${ }^{5}$ Type I telecommunications carriers under the Japanese Telecommunications Business Law are those carriers that use their own infrastructure.

${ }^{6}$ For conflicting views on whether the keiretsu have restricted FDI in Japan, see, e.g. Lawrence (1993) and Weinstein (1996). Both agree, however, that the presence of the keiretsu has restricted the supply of acquirable assets.
} 
when Japan was forced to liberalize its trade and investment regime in the 1960s and 1970s. ${ }^{7}$ Figure 4 shows how the cross-shareholding ratio of the six major horizontal (i.e. bankcentered) keiretsu shot up during this period.

\section{Insert figure 4}

However, since the mid-1990s, these cross-shareholdings, as well as one-way long-term shareholdings, have started to unwind - and have been doing so with increasing speed: quite stable at 17-18 percent and 45 percent respectively until the mid-1990s, they have since dropped markedly (see figure 5). In the case of cross-shareholdings, the ratio has fallen by more than half, reaching 7.4 percent in 2002, while in the case of long-term shareholdings, it has declined by more than a third to 27.1 percent. $^{8}$

\section{Insert figure 5}

Most of this unwinding of cross-shareholdings has been undertaken by financial institutions. ${ }^{9}$ Four main factors are responsible. ${ }^{10}$ The first is the traditionally low profitability of such cross-shareholdings, which deteriorated further during the 1990s amid the deepening recession; what is more, the recession added further incentives to take capital gains in order to compensate for depressed cash flows and, in the case of banks, to obtain funds to write off non-performing loans; the second factor is increased risk-consciousness among banks: the decline in share prices during the 1990s has eroded their capital base and thus threatened their capital adequacy ratio as required by the Bank for International Settlements. The third factor, has been the overhaul of Japanese accounting rules implemented during 1999-2001 to bring these in line with international standards. The changes have exposed the low underlying profitability of most Japanese corporations and again forced financial institutions to reassess their shareholdings - in terms of both their actual valuations and their inherent risk. The mark-to-market rules mean that financial institutions can no longer disguise poor performance - both their own, by using unrealistic book values, and of their shareholdings. The fourth factor, finally, is the introduction of emergency measures in 2001 triggered by impending financial crisis that restrict banks' shareholdings and thus forced them to further reduce their shareholdings.

If cross-shareholdings limited the supply of acquirable assets in the past, then their unwinding in recent years has increased this supply. While this trend has not exactly opened the gates to

\footnotetext{
${ }^{7}$ It remains a matter of debate, however, whether the cross-shareholdings arose with the express purpose of warding off unwanted foreign take-overs or as a result of unrelated government policies. See, for example, Mason (1992) and Weinstein (1997) for conflicting views on this matter.

${ }^{8}$ In fact, not all of the decline in the cross-shareholding and long-term shareholding ratios is due to the unwinding such relationships; another factor is the changing composition of the stock market as new companies with no existing shareholding relationships emerge, reducing the weight of banks and other established companies with long-term shareholding relationships (NLI Research Institute 2003).

${ }^{9}$ In contrast, the cross-shareholding ratio of business corporations has declined only marginally (see Okabe 2001; NLI Research Institute 2002, 2003).

${ }^{10}$ See Okabe (2001), NLI Research Institute (2002, 2003), The Economist (February 4, 1999; November 25 , 1999; October 11, 2001).
} 
hostile takeovers, which are still virtually unheard of in Japan, ${ }^{11}$ the unwinding of crossshareholdings and long-term holdings has increased the proportion of shares held by foreign portfolio investors and Japanese institutional investors which put much greater emphasis on the returns of their investments. ${ }^{12}$ The growing influence of these groups of investors has not only begun to shape the way in which Japanese companies are run but has also lowered one of the barriers to M\&As and hence foreign direct investment in Japan.

\section{Changes in accounting rules and measures to facilitate mergers and corporate restructuring}

As already mentioned, Japanese accounting standards were substantially revised in 19992001 to bring them in line with international standards. The two most important of these changes concern the consolidation of subsidiaries finances and the valuation of securities holdings. Whereas in the past, firms were able to hide financial losses by moving these offbalance-sheet, the new book-keeping rules aim to prevent such practices by requiring the finances of partly-owned subsidiaries to be consolidated with those of the parent. Moreover, companies must now value their securities holdings at market price rather than at book value, making it more difficult to gloss over poor results by selling or revaluing share holdings. ${ }^{13}$

The improved transparency of Japanese corporate accounts has facilitated M\&As in at least three important ways. First, it contributed to the unwinding of cross-shareholdings, as mentioned above. Second, greater transparency has reduced the risk for foreign companies to find hidden liabilities when acquiring a Japanese firm. And third, the accounting changes have forced Japanese companies to re-examine their operations and in many cases have led them to sell unprofitable divisions or subsidiaries. ${ }^{14}$

Such sales, moreover, have been simplified by several pieces of legislation passed between 1997 and 2000 aimed at streamlining merger procedures and facilitating corporate restructuring more generally. For example, the way was cleared for stock swaps which are frequently used to finance M\&A deals. Other measures include the lifting of the ban on holding companies and the revisions of the procedures regarding corporate spin-offs. For example, firms no longer are required to notify and gain approval from all creditors individually in advance of a merger or spin-off but now only need to put a notice in a daily newspaper. In the case of a spin-off, moreover, a company had to assess the value by a courtappointed lawyer and the part to be spun off had to stop operations during that period, which could take as much as six months or a year. ${ }^{15}$

Taken together, the recent reforms of Japan's accounting practices and regulations relating to mergers, spin-offs and holding companies have greatly increased the transparency and flexibility of the market for corporate acquisitions. Consequently, the number of M\&As

\footnotetext{
${ }^{11}$ A rare exception was the acquisition of International Digital Communications (IDC) by Britain's Cable \& Wireless which received large media coverage as it was widely seen as the first hostile takeover of a Japanese company (Businessweek, May 24, 1999; The Economist, November 25, 1999). The case illustrates both the extent to which Japan's economy has indeed changed and the extent to which it still remains different from Anglo-Saxon-style capitalism.

${ }^{12}$ See, e.g., Okabe (2001).

${ }^{13}$ The Economist, November 25, 1999.

${ }^{14}$ See Japan Research Institute (2002). Of course, the urgency of reassessing the profitability of individual operations has increased with the growing share ownership of foreign and domestic institutional investors and their emphasis on investment returns, demonstrating how the different developments are closely interlinked and often reinforce each other.

${ }^{15}$ Muramatsu (2001) and Poe, Shimizu and Simpson (2002).
} 
conducted in Japan has risen dramatically over the past ten years: in-in M\&As increased from less than 300 cases during the mid-1990s to 1,354 in 2002, while out-in M\&As jumped from around 30 per year to a peak of 175 in 2000, before dropping to 129 in $2002 .{ }^{16}$ Of course, the number and value of annual M\&A deals in Japan still lags considerably behind those in the U.S. (even after accounting for the difference in the size of the two economies): for 2002, Thomson Financial recorded 1,132 completed M\&A cases worth 70.8 billion US\$ in Japan vis-à-vis 5,914 cases worth 561.5 billion US\$ in the United States. However, as a result of the recent increase in M\&A activity in Japan, the gap with the U.S. and other developed countries has narrowed substantially. In fact, while M\&A activity in the U.S. and Europe experienced a lull in 2003, it expanded further in Japan, propelling the country into third place in terms of number and value of M\&A deals, behind only the United States and Britain and ahead of Germany and France. ${ }^{17}$

\section{Falling costs and weak companies}

Another constraint on foreign direct investment in the past was that Japan simply was an expensive place to do business in. Among other things, foreign businessmen frequently complained about the high wages, land costs and office rents in Japan. ${ }^{18}$ What is more, even if companies had been available for acquisition, the high price of Japanese shares and high price-earnings ratios acted as a constraint. Following the collapse of the bubble economy, asset prices, wages, and even the consumer price level have all fallen dramatically: after reaching almost 39,000 points at the end of 1989, the Nikkei 225 index rapidly shed more than 50 percent of its value and at one point, in 2002, was four-fifth below its all-time high; similarly, average urban land prices have dropped by 45 percent since peaking in 1991, while commercial property prices have fallen even more - by 60 percent. Meanwhile, the yen, which had been strengthening vis-à-vis the US dollar during the first half of the 1990s, declined during 1996-98, though it has since stabilized (see figures 6 to 8). Consumer prices and nominal wages have been falling since 1998, and since 2000, even real wages have been dropping. The cumulative result of these trends is that the cost of doing business in Japan has declined and made buying a Japanese company much more affordable.

\section{Insert figures 6 to 8}

In fact, the prolonged recession has considerably weakened Japan's corporate sector. The number of bankruptcies rose throughout the decade, while total liabilities reached record levels, jumping from less than 5 trillion yen before the 1990s to a peak of 24 trillion yen in 2000 (see figure 9). ${ }^{19}$ As a result, a number of Japanese companies have had to be bailed out sometimes by foreigners, such as in the case of the Long Term Credit Bank and Kyoei Life

\footnotetext{
${ }^{16}$ Recof (2003), Nihon Kigyo no M\&A Databook [M\&A Databook of Japanese Companies].

${ }^{17}$ Of course, for a proper comparison, these figures would need to be put in relation to the size of the economy of, or the number of firms in, each country. Nevertheless, the catch-up is quite impressive. According to Thomson Financial, the number and value of M\&A deals in Japan in 2003 rose to 1,376 cases worth 71.8 billion US\$, while those in Germany fell from 958 cases worth 79.2 billion US\$ in 2002 to 859 cases worth 41.8 billion US\$ in 2003 and those in France dropped from 729 cases worth 77.0 billion US\$ to 561 deals worth 59.6 billion US\$. (Source: Thomson Financial press release. Online: http://www.thomson.com/cms/assets/pdfs/financial/ league_table/mergers_and_acquisitions/4Q2003/press_releases/4Q03_MA_PR_World_US_Finl_Adv.pdf)

${ }^{18}$ See Jordan (1996) for a typical example of foreign businesses' complaints about high costs in Japan.

${ }^{19}$ Data for the period before 1994 is read off the charts available on the Teikoku Database website: http://www.tdb.co.jp/tosan/syukei/03nen.html (31 March 2004).
} 
Insurance. In other cases, financial difficulties have forced firms - among them some of the country's largest and most famous, such as Nissan and Mitsubishi Motors - to accept foreign participation to ensure long-term survival.

Insert figure 9

\section{Changing attitudes towards foreign companies}

The continuing deterioration of the Japanese economy, culminating in a growing sense of gloom in the years 1998-2002 as the recession deepened and the country again seemed on the brink of financial crisis, has led to a widespread change of attitude towards foreign direct investment among policy-makers, businessmen and the public. Official resistance, for example, has given way to efforts to attract foreign capital. A council to promote foreign direct investment headed by the prime minister was set up as early as 1994, publishing a string of statements stressing the importance of attracting FDI. Government-backed bodies such as the Japan External Trade Organization (JETRO) and the Development Bank of Japan (DBJ) provide information and consulting services, and since the early 1990s, various incentives have been offered to foreign firms investing in designated industries and special Foreign Access Zones. ${ }^{20}$

The attitude of Japanese business to foreign direct investment has also changed considerably. While in earlier decades, Japanese companies often colluded with the bureaucracy to block the entry of foreign competitors, in the 1990s foreign firms were increasingly seen as important allies in pressing for structural reform. ${ }^{21}$ Since the middle of the decade, the Japanese business federation Keidanren has repeatedly called on the government to deregulate the economy in order increase international access to Japan's market and encourage new foreign direct investment. ${ }^{22}$

Of course, old habits die hard, and official pronouncements by politicians and business groups are one thing, while the reality may be quite different. In this respect, the hostile takeover by Cable \& Wireless of IDC in 1999 represents an instructive case study. IDC's sale to NTT had seemed a foregone conclusion and when C\&W made a rival offer, it was promptly rejected by minority shareholders such as Toyota and Itochu. However, politics hung closely over the battle that followed, with both British and EU officials reportedly keeping a close eye on the negotiations. After both NTT and C\&W had raised their offers, minority shareholders, led by Toyota, finally agreed to the sale to C\&W. Toyota's maneuvering during the episode shows how the company was torn between traditional Japanese values, such as seeking to guarantee workers' job security, and the need to avoid international repercussions, both for Japan and its own business. Similarly, the government was generally perceived as taking a neutral stance, though the Ministry of Posts and Telecommunications said afterwards that it would monitor the takeover to ensure that IDC maintains "Japanese style-employment practices." 23 The case thus suggests that, though their natural reflexes may still be different, both government

\footnotetext{
${ }^{20}$ Muramatsu (2001); JETRO website.

${ }^{21}$ On efforts by Japanese business to block the entry of foreign competitors during the 1960s and 1970s see, for example, Mason (1992).

${ }^{22}$ See, e.g., the address of Keidanren Chairman Toyoda to the Keidanren general assembly in 1995 (available online: http://www.keidanren.or.jp/english/speech/spe005.html; 31 March 2004) and Keidanren proposals for an improvement of the Japanese investment environment (available online: http://www.keidanren.or.jp/english/ policy/2002/042/proposal.html; 31 March 2004).

${ }^{23}$ The Economist, November 25, 1999; The Japan Times, April 15, 1999; June 2, 1999; June 11, 1999.
} 
officials and business leaders in the end stuck by their professed commitment to allowing foreign companies equal to access to the Japanese market.

What is more, one might even suspect that in their comments regarding job security and employment practices, Toyota spokesmen and Ministry officials were to some extent simply going through the motions they thought the public expected of them. Yet, it seems that even the public no longer is overly concerned about the growing role of foreign business in general and the takeover of Japanese companies in particular. Probably no single person has contributed more to this change of perception than Carlos Ghosn, the CEO installed at Nissan after the take-over by Renault. The first moves of "the cost-cutter," as he was known, included the closure of five factories and the cutting of 21,000 jobs worldwide, confirming Japanese concerns about hard-nosed Western management practices. Yet, the spectacular turn-around from record losses to successive record profits in the space of only two years has turned Ghosn into a business icon in Japan. As a result, foreign takeovers of Japanese companies have hardly raised an eyebrow in recent years.

\section{Labor market changes}

One of the areas where the changes in attitudes are most easily discernable, and have the greatest impact on the operations on foreign companies in Japan, is the labor market. The difficulties faced by foreign companies in hiring qualified personnel, and the resulting high wage costs, used to be among foreign executives' most frequent complaints. The reluctance of the Japanese to work for foreign companies - and its weakening - is closely bound up with the Japanese employment system and its gradual erosion as a result of the prolonged recession.

Central to this issue is the so-called lifetime employment system. While far from universal, ${ }^{24}$ lifetime employment has been most widespread among Japan's professional elite and is closely intertwined with the country's education system, which has generally provided young people with excellent training through high school but has lagged behind other Western countries in producing Ph.D.s and other highly trained professionals such as lawyers or engineers. This gap has traditionally been filled by Japanese companies, who have provided their employees with world-renowned on-the-job training. However, in order to prevent workers from leaving once their expensive training is complete, firms typically paid employees little at the beginning of their careers but raised their salaries rapidly towards the end, thus rewarding lifelong dedication to the company and discouraging mid-career changes. The second and complimentary cornerstone in this arrangement has been firms' commitment to their employees. To be able to attract employees, firms needed to be well-established in the market and have a reputation for not laying off worker at the first sign of trouble, i.e. before employees reaped the rewards for accepting low starting salaries. This explains why historically, and even today, Japanese firms have been reluctant to lay off workers even in difficult times. The upshot of this lifetime employment system is that Japan's labor market has been extremely rigid when compared with the countries of the West, forcing foreign companies - unwilling or, as new-comers, unable to credibly guarantee lifetime employment - to pay considerably higher salaries than their Japanese competitors in order to attract qualified personnel.

However, this pillar of Japanese-style capitalism, too, has been eroded in recent years amid the deepening recession as Japanese companies were no longer able to stick to their side of

\footnotetext{
${ }^{24}$ Lifetime employment is generally confined to full-time employees at one of the big companies, i.e. around one-third of all workers.
} 
the bargain. Their initial response to the worsening economic conditions had been to stop hiring new graduates, leading not only to a jump in unemployment among the young, but also doing little to lower wage bills as the average age of employees rose. Yet, with no upturn in sight, firms were increasingly compelled to across-the-board job cuts, culminating in a spate of mass lay-offs during 1999-2001. In early 1999, even before Ghosn's radical restructuring plan for Nissan involving the loss of 21,000 jobs, Sony had announced it would cut its global workforce by 17,000 , while at NEC some 15,000 jobs were to go. A second wave followed in the autumn of 2001, when amid the global downturn in the IT sector the four electronics makers Fujitsu, Toshiba, Hitachi, and Matsushita alone announced job cuts totaling more than 60,000 . These headline figures relate to the global operations of the companies concerned. But whereas in the past, jobs cuts were mainly confined to overseas operations, for the first time Japanese firms were also laying off workers at home.

News such as these as well as the inexorable rise in the unemployment rate from 2.0 percent in 1990 to a peak of 5.5 percent in 2002 have seriously undermined the faith in the lifetime employment system and contributed to an increased willingness to work for a foreign company. What is more, the new job insecurity has dealt a serious blow to the image of the sarariman, hitherto respected as the "corporate warrior" that rebuilt Japan, but now often portrayed as a sad, middle-aged man who has dedicated his life to the company for little reward. It is therefore comes as little surprise that a recent survey by a job agency found that only 31 percent of university graduates were planning to work for the same company until retirement age, while 41 percent indicated they wanted to hop jobs to develop their careers. ${ }^{25}$ The change in attitudes is also reflected in the growing attractiveness of foreign companies: in an annual survey among university graduates asking them to name the most desirable companies to work for, foreign firms have been steadily moving up the ladder. ${ }^{26}$

\section{$4 \quad$ Push or pull?}

To be sure, the regulatory and structural changes over the past decade or so have done away with many of the formal and informal barriers that in the past hampered foreign business activity in Japan, paving the way for the surge in inward FDI flows. Yet, does this mean that the country all of a sudden has become a magnet for global investment? Or has it simply benefited from the worldwide boom in FDI? A closer inspection of aggregate FDI flows, their sectoral composition, and the relationship between investment trends in particular industries and changes in the business environment, provides some clues. These suggest that, at least until 2001, foreign direct investment in Japan was primarily driven by global trends. However, it does seem as though inflows may have developed a momentum of their own in 2002.

\section{Aggregate FDI flows}

For a first, intuitive indication that FDI into Japan may have been primarily driven by global developments, all that is needed is a brief glance at both trends (see figure 10): both the timing and the magnitude of FDI into Japan are highly correlated with global flows. Both in Japan and worldwide, the largest surge occurred in 1998 and 1999, investment flows peaked

\footnotetext{
${ }^{25}$ Mainichi Daily News, January 11, 2004. Online: http://mdn.mainichi.co.jp/news/archive/200401/10/ 20040110p2a00m0dm011001c.html (April 6, 2004).

26 JETRO, New Business Practices and Opportunities in the Japanese Economy. Online: http://www.jetro.org.au/sydney/publi/econ_practices.pdf
} 
in 2000 and then contracted. ${ }^{27}$ Similarly, in both cases, inflows at the end of the decade (1998-2000) exceeded those at the beginning (1991-93) by a factor of about five. This means that Japan's share of global inward FDI during this period has virtually stagnated or at best seen a very modest increase, depending on what periods are chosen for comparison (see figure 11 and table 2). For example, during the first half of the 1990s, only 0.4 percent (1991-1995) of worldwide investment flows found their way to Japan; yet, even during the boom in the second half of the decade, the figure was only marginally higher at 0.7 percent (1996-2000), a level comparable with the 0.6 percent registered in $1981-1985 .{ }^{28}$ What is more, Japan's share in global FDI stocks in fact dropped from 1.1 percent in 1995 to 0.8 percent in 2000-2002.

Insert figures 10 and 11

Compare these figures with those for the United States or China, which in contrast to Japan have acted as genuine magnets for global investment flows during the 1990s. Following its opening up at the beginning of the decade, China has attracted huge amounts of direct investment by companies from around the world lured by the promises of a rapidly expanding market of a billion consumers and a seemingly inexhaustible supply of cheap labor. As a result, the country's share in global FDI inflows jumped from 1.8 percent in 1986-1990 to 9.9 percent in 1991-1995. Though this dropped again during the second half of the decade, China's share in global FDI stocks continued to grow from 4.6 percent in 1996 to 6.3 percent in 2002 (see table 2). Similarly, while the share of the United States in global FDI flows in halved during 1991-95 when compared with the preceding five-year period, it then grew again by more than six percentage points to 23.8 percent in the second half of the decade. Foreign investors where attracted to America by the opportunities offered by the longest expansion in post-war history. Compared with these increases by several percentage points, the rise in Japan's share in global FDI flows by 0.3 percentage points is just a blip. The comparison with these two countries also points to a likely explanation why Japan's share in global FDI did not expand in a similar fashion: the country offers neither low production costs (like China) nor a rapidly expanding market (like China and the U.S.) that multinationals cannot afford to ignore.

\section{Insert table 2}

\section{Sectoral trends}

While Japan's share in global inward FDI did not increase substantially at an aggregate level, it could still be the case that deregulation and structural change exerted a pull on investment in certain sectors of the economy. Yet, here again a closer look reveals that Japanese trends where primarily shaped by global ones: in four out of the six most important sectors, FDI into Japan closely followed worldwide patterns.

\footnotetext{
${ }^{27}$ Figure 1 is based on MOF data which registers FDI on a notification basis. The correlation is less strong on the basis of UNCTAD balance-of-payments data, according to which Japanese inward FDI actually stagnated in 1998, but then rose fourfold in 1999, which also represents the peak. However, the striking co-movement over the past decade remains fundamentally unchanged.

${ }^{28}$ Calculations based on UNCTAD data.
} 
Globally, only four sectors accounted for the lion's share of the surge in M\&A activity during 1998-2000: telecommunications, finance, machinery, and business services. ${ }^{29}$ Together, these accounted for 62.1 percent of the value of all M\&As in that period and for a full 72.4 percent of the increase when compared with the preceding three-year period. In the case of Japan, the concentration of inward FDI in these sectors is even more pronounced: they accounted for 77.0 percent of total inflows during 1998-2000 and for 85.4 percent of the increase when compared with 1995-97 (see figure 12). What is more, as figure 13 demonstrates, the sectoral trends of global M\&As and FDI inflows into Japan are highly correlated in the telecommunications, finance, and machinery industries, though less so in the business service sector. $^{30}$

Insert figures 12 and 13

Two other sectors in which Japan has received substantial FDI inflows in the past, but whose role has been somewhat eclipsed by the surge in the four industries just mentioned, are trade and chemicals. These two sectors accounted for a third of Japanese FDI inflows during 199597, but saw this share halve during 1998-2000. Nevertheless, both also experienced considerable increases, and in the case of the trade sector, the pattern was again highly correlated with global trends (figure 13). Thus, the only sector of importance in which inward FDI did not closely follow worldwide flows is the chemical industry. ${ }^{31}$ In sum, looking at the six industries that accounted more than 90 percent of FDI into Japan during the surge in 1998-2000 confirms the view that sectoral trends, like aggregate flows, where primarily driven by the global boom in M\&A activity during this period.

\section{Investment dynamics and the business environment}

Finally, for a more differentiated view, it is quite useful to consider the sectoral trends by looking at some of the individual M\&A cases and relate these to the deregulatory measures and structural changes that have transformed the business environment in Japan. Three sectors in particular will be examined: automobiles, telecommunications, and finance. Though the overall picture remains unchanged, what emerges is that in each of these sectors, quite a different set of factors have played a role in shaping the investment dynamics.

The two major M\&As that have dominated foreign investment in the automotive industry have already been mentioned: the acquisition of controlling stakes in Nissan by Renault and in Mitsubishi Motors by DaimlerChrysler. However, there were also a number of deals on a somewhat smaller scale: after Nissan was acquired by Renault, one of the first moves of the new management was to merge two of its affiliated parts suppliers, Calsonic and Kansei, and then sell a stake in the newly created Calsonic Kansei to America's Delphi, the world's largest maker of auto parts. A few months earlier, German parts maker Bosch had already

\footnotetext{
${ }^{29}$ A global breakdown of FDI by sector is not available, so that figures on M\&As are used.

${ }^{30}$ Regressing FDI inflows into Japan on global M\&As for the period 1989-2002 yields coefficients significant at the 1 percent level for the telecommunications, finance, and machinery sectors, and significant at the 5 percent level for business services. The adjusted R-squared ranges from 38 percent in the case of business services to more than 70 percent in the case of finance and telecommunications.

${ }^{31}$ Regressing FDI inflows on global M\&As, the coefficient for the trade sector is also significant at the 1 percent level (adjusted R-squared: 58 percent), while that for the chemical industry is insignificant.
} 
increased its interest in injection pump maker Zexel, another of Nissan's suppliers, from 32 to just over 50 percent.

Foreign investments in this sector have faced no specific regulatory barriers for decades. Ford of the U.S., for example, entered a capital tie-up with Mazda as early as 1979, while General Motors had acquired substantial interests in Fuji Heavy Industries, Isuzu and Suzuki. ${ }^{32}$ What was new about the acquisition of Nissan and Mitsubishi Motors, though, was that Renault and DaimlerChrysler both acquired controlling stakes and then installed foreign executives. This, of course, was only possible because of the dire financial situation of the Japanese companies. ${ }^{33}$ Yet, the international context is also important: at the time, it was predicted that in the future, probably only a handful of car makers would remain independent and European companies were seeking to strengthen their position in Asia. The acquisitions were therefore part of a global consolidation in the car industry.

In contrast with the automotive sector, deregulation has played a more important role in the telecommunications and the finance industry. The lifting of foreign investment restrictions for type I carriers in the telecommunications sector in 1998 paved the way for acquisitions in this field. Again, two cases take center-stage: IDC, which was taken over by Cable \& Wireless for 699 million US\$, and especially Japan Telecom. In September 1999, British Telecom and AT\&T bought stakes in Japan Telecom worth 1.83 billion US\$, while Vodafone acquired a 15 percent share worth 2.2 billion US\$ in December 2000. Purchasing British Telecom's and AT\&T's stake for a combined 6.7 billion US\$ in the spring of 2001, Vodafone subsequently raised its investment by another 2.64 billion US\$ in October of the same year for a controlling interest of 69.7 percent. Adding up these sums involved, the takeover of Japan Telecom involved the tidy amount of 13.4 billion US\$. Comparing this figure with the total inward FDI in the sector for the three-year period 1999-2001 of 16.4 billion US\$ (on a notification basis), it becomes clear that the surge was due almost exclusively to the takeover of one single company. ${ }^{34}$ This certainly would not have been possible without the liberalization of foreign ownership in the industry. However, had it not been for the global M\&A boom in the sector during that period, it is doubtful that investment in Japan would have reached anything near the level it did.

Probably the most convincing case that deregulation and structural change have acted as an enticement to foreign investment in Japan can be made for the financial sector. Banks and insurance companies used to form the core of the keiretsu and play a central role in the unwinding of cross-shareholdings, which hitherto had limited the availability of acquirable

\footnotetext{
${ }^{32}$ As a result of the Nissan and Mitsubishi Motors deals, which also involved their respective affiliates, Nissan Diesel and Mitsubishi Fusan, only two of Japan's twelve car makers, Toyota and Honda remain independent, while eight now have foreign partners. Toyota holds stake in the remaining two, Daihatsu and Hino.

${ }^{33}$ In early 1998, Nissan and Mitsubishi Motors each had debts amounting to around 2 trillion yen (about 16 billion US\$ at the prevailing exchange rate).

${ }^{34}$ Admittedly, this calculation is rather rough-and-ready, relying on figures published in various press reports without any detail on how the deals were financed. It is therefore possible that part of the 13.4 billion US\$ involved in the purchase of Japan Telecom were raised in Japan and therefore do not represent capital inflows. MOF data, however, suggest, that most of this sum did come from abroad. Vodafone channelled its investment in Japan Telecom through its subsidiary in the Netherlands, and matching data on inward FDI by country (with no breakdown by industry available) and by industry (broken down only by region) suggests a huge jump in FDI in the telecommunications sector from the Netherlands in the region of 7 billion US\$ in 2001 alone.

Another problem with the figures is that they double count the investment by BT and AT\&T subsequently sold on to Vodafone. As this applies to both the headline figures and MOF notification data, this presents no problems in terms of the calculation above. However, on a BOP basis, the re-sale of BT's and AT\&T's stake would show up as a negative inflow, i.e. the MOF data overstate the extent of foreign investment. Unfortunately, FDI data on a BOP basis broken down by industry are presently unavailable.
} 
assets; non-performing loans and the slump in the stock-market have pushed a large number of banks and insurance companies to, and in quite a few cases over, the verge of bankruptcy; and the Financial System Reform Law passed in 1998 sufficiently liberalized the sector to introduce competition into the market and allow foreign firms to take advantage of their superior management methods and products.

While foreign investment in the automobile and the telecommunications sector revolved largely around mega-deals involving less than a handful of targeted companies, this is not the case in the financial sector. To be sure, the sector has also seen a number of deals breaking through the billion US\$ barrier, topped by the 6.6 billion US\$ acquisition of Japan Leasing Corporation by GE Capital. But the surge in foreign investment is much more distributed across a larger number target companies, ranging from banks via equipment financing to insurance. In fact, foreigners have bought a collapsed bank (the Long-Term Credit Bank of Japan) and more than half a dozen failed insurance companies. What is more, though FDI into Japan in this sector closely followed the global pattern, rising steeply until 2000 and contracting the following year, on a notification basis it grew again in 2002 - in contrast with M\&As worldwide.

\section{Bucking the trend?}

The financial sector is not the only industry in which FDI flows into Japan bucked the global trend in 2002. As can be seen in figure 13, the country also saw a large rise in FDI in the chemical industry and more modest ones in business services and in trade, while global out-in M\&A activity in these sectors continue to contract. As a result, total inflows in Japan also recovered, in contrast with global FDI flows (figure 10).

Whether this means that FDI inflows into Japan are beginning to follow their own trajectory rather than simply mirroring global trends is at present difficult to judge. What data are available for 2003 are sending mixed signals. MOF data for the first half of the year indicate that, on a notification basis, FDI in Japan continued to rise, registering a 55 percent increase when compared with the same period of 2002. What is more, while M\&A activity in Europe and the United States shrank further in 2003, the value of completed deals held steady in Japan, and that of announced M\&As even rose by 43 percent. ${ }^{35}$ Announced M\&As involving a foreign buyer experienced an even larger jump: according to Thomson Financial, crossborder investment into Japan reached 12.45 billion US\$, a year-on-year increase of 78 percent. ${ }^{36}$ In stark contrast, FDI figures on a BOP basis, which record actual capital flows rather than planned investments and also include withdrawals, show that FDI in 2003 actually dropped by 36.7 percent (figure 14). Given such conflicting evidence, serious doubts remain whether foreign direct investment in Japan could increase significantly without another global push.

Insert figure 14

\footnotetext{
35 Thomson Financial press release. Online: http://www.thomson.com/cms/assets/pdfs/financial/league_table/ mergers_and_acquisitions/4Q2003/press_releases/4Q03_MA_PR_World_US_Finl_Adv.pdf

36 Thomson Financial press release. Online: http://www.thomson.com/cms/assets/pdfs/financial/league_table/ mergers_and_acquisitions/4Q2003/press_releases/4Q03_MA_PR_Japan_Finl.pdf
} 


\section{Conclusion}

Without question, the recent surge of FDI into Japan is an important development in a country that so far has seen relatively little of it. Domestic regulatory, structural and other changes have played a crucial role in making the country more receptive to foreign participation in the economy, and higher levels of inward FDI, along with greater M\&A activity, look like they are here to stay. Yet, as the detailed analysis has shown, it is unlikely that, by themselves, domestic changes would have triggered a rise in FDI anywhere near the scale actually observed had it not been for the FDI boom sweeping the globe during 1998-2000. Thus, on balance, the massive push of global investment flows, spilling over into Japan, seems to have been more important than the pull exerted by any Japan-specific factors.

More recent data, as far as they are available, indicate that FDI inflows into Japan may be beginning to develop a momentum of their own. Should this indeed be the case, then what may actually be happening is that foreigners - who have for years and decades heard and sung only one tune, namely, that Japan is a very difficult place to do business in - are slowly beginning to change their perception, thanks to the recent surge in inward investment. On the other hand, any "Japan enthusiasm" could also be easily dampened. Many foreign insurance companies, for example, are finding it difficult to make their acquisitions in Japan profitable. ${ }^{37}$ And while the Renault-Nissan alliance in the car industry has proved to be an impressive success, that between DaimlerChrysler and Mitsubishi Motors has turned out to be an equally impressive failure. In fact, in April, the German company decide to abandon its Japanese partner to its fate after the Japanese carmaker's finances spiraled out of control. ${ }^{38}$ Such news serve as a reminder that as long as Japan's economic problems persist, foreign companies may find it easier to make money in the more vibrant parts of Asia.

Overall, it seems unlikely that the government's ambitious target of doubling the stock of foreign direct investment in Japan by 2008 can be achieved without another acceleration in global FDI flows. To be sure, even a relatively small presence of foreign companies can have a potentially large impact in specific markets by offering new, better, or cheaper products to consumers and forcing competitors to shape up. In fact, a number of cases - such as the Starbucks coffee-chain or retailer Toys-R-Us - demonstrate that this is already happening. ${ }^{39}$ But the impact, and the potential gains, would be even greater if foreign direct investment reached not only higher levels, but also a wider spectrum of the Japanese economy.

\footnotetext{
${ }^{37}$ The Economist, June 5, 2003.

${ }^{38}$ Financial Times, April 22, 2004.

${ }^{39}$ A case study of Starbucks in Japan can be found on the website of the American Chamber of Commerce in Japan (ACCJ): http://www.accj.or.jp/ document_library/ FDICaseStudies/1069040679.pdf
} 
References:

Feenstra, R.C. (1999) 'Facts and fallacies about foreign direct investment', in M. Feldstein (ed.) International Capital Flows, Chicago: University of Chicago Press. Also online: http://www.econ.ucdavis.edu/faculty/fzfeens/pdf/fdi2.pdf

Japan Research Institute (2000) 'The impact of foreign direct investment (FDI) in Japan on the Japanese economy’, Monthly Review, September. Online: http://www.jri.co.jp/ research/archives/MonthlyReview-e/pdf/MRe200009fdi.pdf

Jordan, T.F. (1996) 'The future of foreign direct investment in Japan', in M. Yoshitomi and E.M. Graham (eds.), Foreign Direct Investment in Japan, Edward Elgar, Cheltenham, UK.

Lawrence, R.Z. (1993) 'Japan’s low levels of inward investment: the role of inhibitions on acquisitions', in K.A. Froot (ed.), Foreign Direct Investment, Chicago: University of Chicago Press.

Mason, M. (1992) American Multinationals and Japan: the political economy of Japanese capital controls, 1899-1980, Cambridge, Mass.: Council on East Asian Studies, Harvard University.

Muramatsu, S. (2001) 'Foreign capital and the recent M\&A environment in Japan', in A. Holzhausen (ed.), Can Japan Globalize? Studies on Japan's changing political economy and the process of globalization in honour of Sung-Jo Park, Physica-Verlag, Heidelberg \& New York.

NLI Research Institute (2002) 'Cross-shareholdings decline for the $11^{\text {th }}$ straight year (FY 2001 survey)’. Online: http://www.nli-research.co.jp/eng/resea/econo/ eco021001.html

_ (2003) 'The relationship of companies and banks as cross-shareholdings unwind fiscal 2002 cross-shareholding survey’. Online: http://www.nli-research.co.jp/eng/resea/econo/eco031118.html

Okabe, K. (2001) 'Are cross-shareholdings of Japanese corporations dissolving? - Evolution and implications', Nissan Occasional Paper Series, No. 33, Oxford University. Online: http://www.nissan.ox.ac.uk/nops/nops33.pdf

Poe, M., K. Shimizu and J. Simpson (2002) 'Revising the Japanese commercial code: a summary and evaluation of the reform effort', Stanford Journal of East Asian Affairs, Spring, Vol. 2. Online: http://www.stanford.edu/group/sjeaa/journal2/ japan2.pdf

Weinstein, D. (1996) 'Structural impediments to investment in Japan: what have we learned over the last 450 years?', in M. Yoshitomi and E.M. Graham (eds.), Foreign Direct Investment in Japan, Edward Elgar, Cheltenham, UK.

Weinstein, D. (1997) 'Foreign direct investment and keiretsu: rethinking U.S. and Japanese policy’, in R.C. Feenstra (ed.), The Effects of U.S. Trade Protection and Promotion Policies, Chicago: University of Chicago Press. 
$\underline{\text { Figures and Tables }}$

Figure 1: FDI in Japan (million US\$; notification basis)

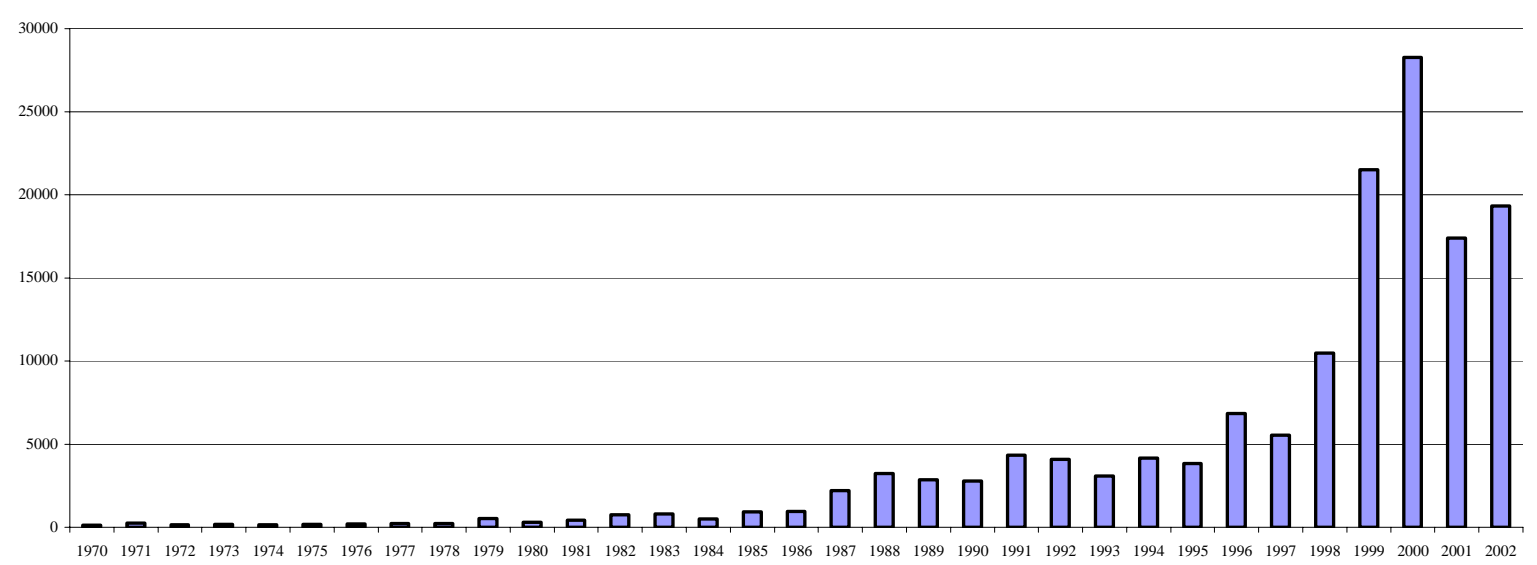

Source: 1970-2001: JETRO White Paper 2002; 2002: MOF data in yen are converted into US\$ following the JETRO example using the Bank of Japan interbank exchange rate.

Figure 2: Japanese out-in M\&As and inward FDI (million US\$; BOP basis)

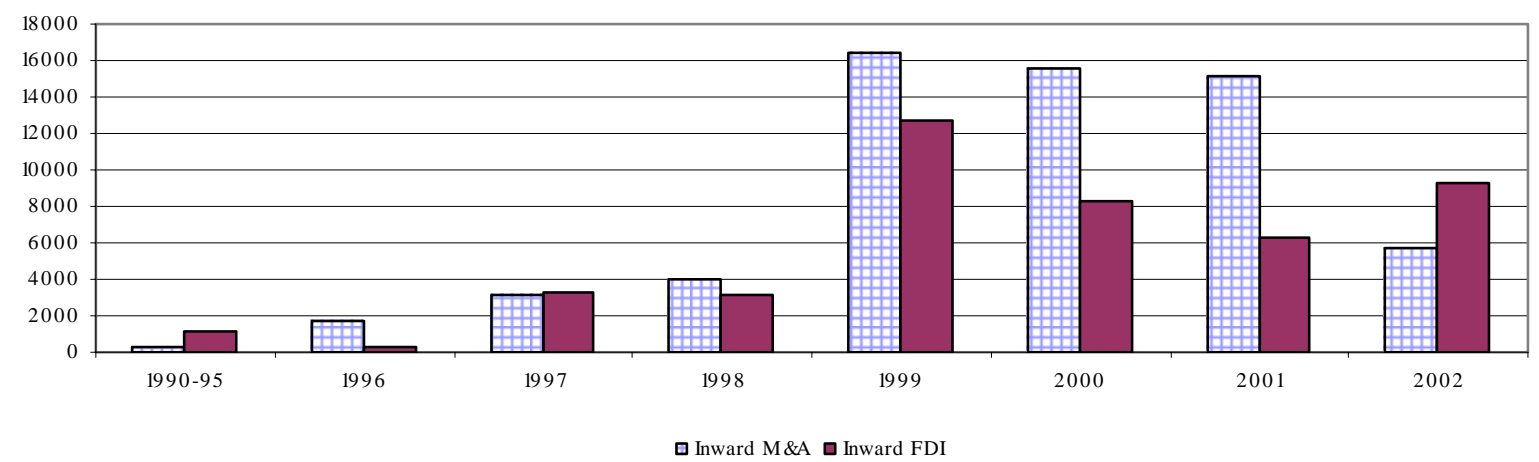

Source: UNCTAD (2002; 2003).

Figure 3: Global inward FDI flows (million US\$)

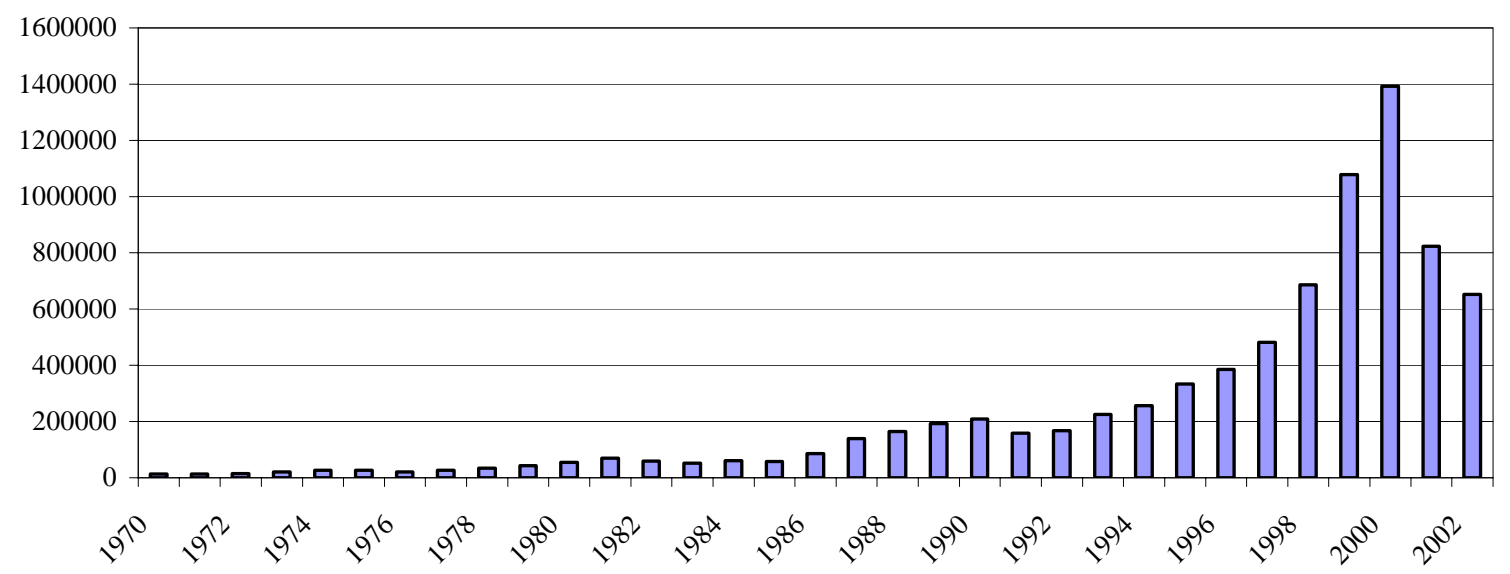

Source: UNCTAD. Online: http://www.unctad.org/Templates/Page.asp?intItemID=1923\&lang=1 
Figure 4: Intra-keiretsu shareholding ratio ( percent)

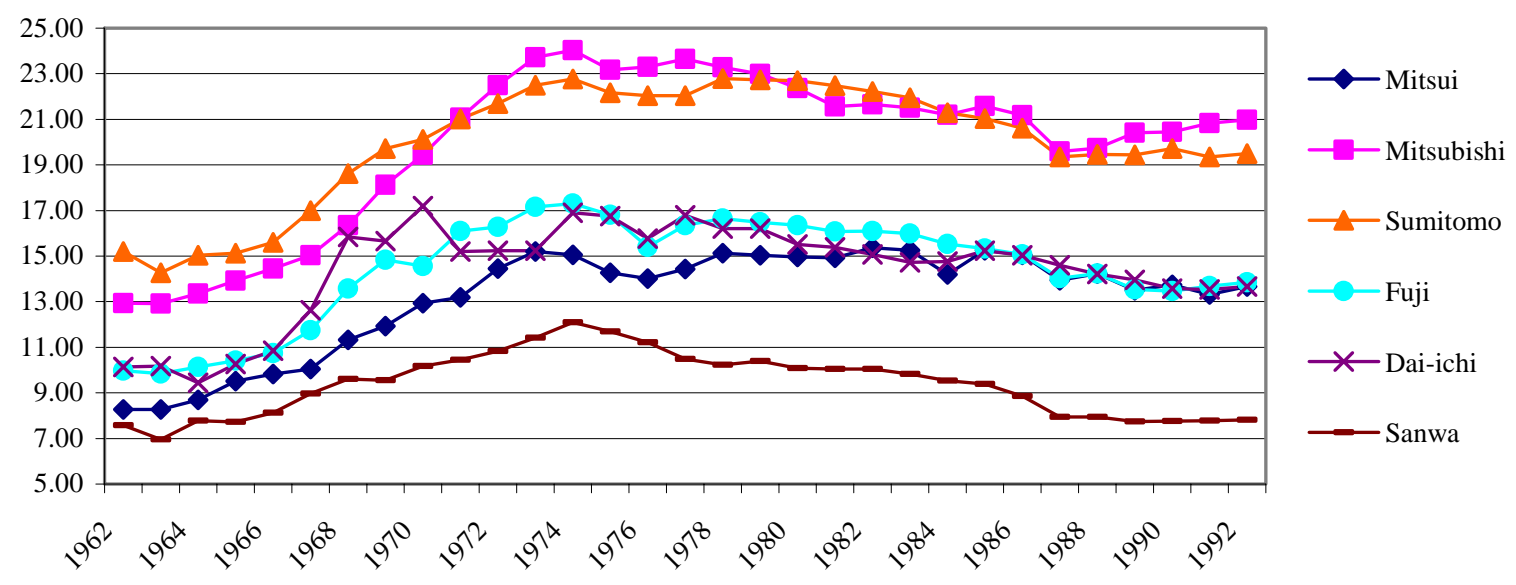

Source: Keiretsu no Kenkyu (various issues).

Figure 5: Cross- and long-term shareholding ratio ( percent)

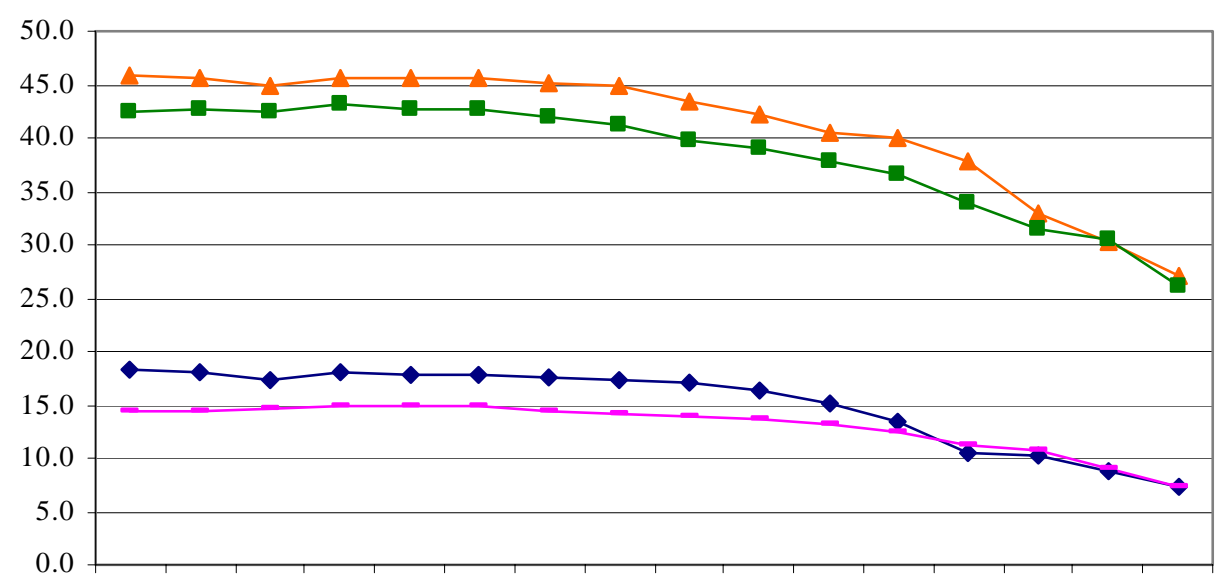

$\multimap$ Cross-holding Value

_ _ Cross-holding Unit share

$\longrightarrow$ Long-term holding ratio Value

$\longrightarrow$ Long-term holding ratio Unit share

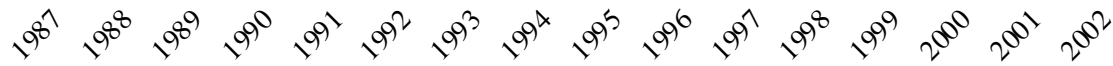

Source: NLI Research Institute.

Figure 6: Urban land prices $(1991=100)$

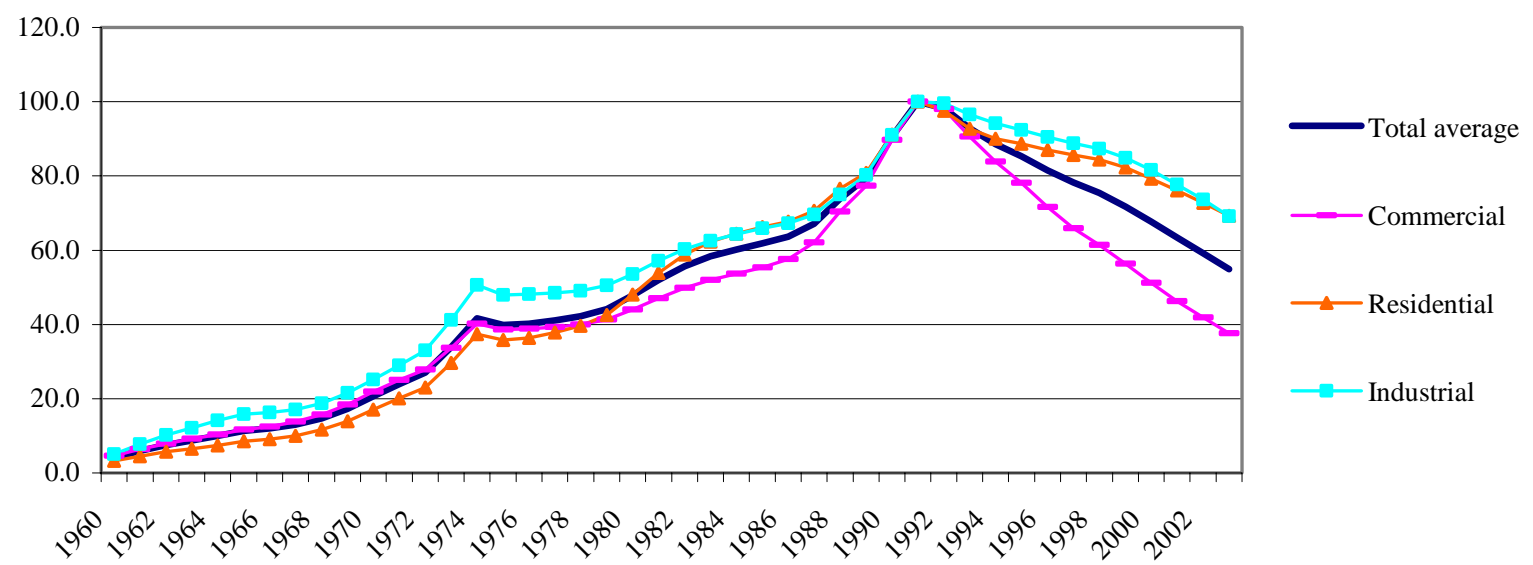


Figure 7: Nikkei stock average



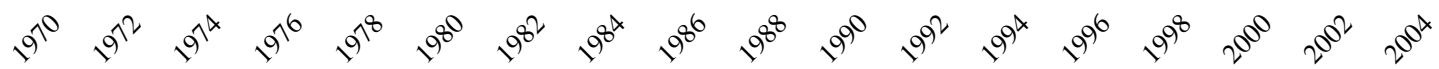

Source: Bank of Japan. Online: http://www2.boj.or.jp/en/dlong/etc/data/ehstock.txt

Figure 8: Yen/US\$ exchange rate (inverted scale)

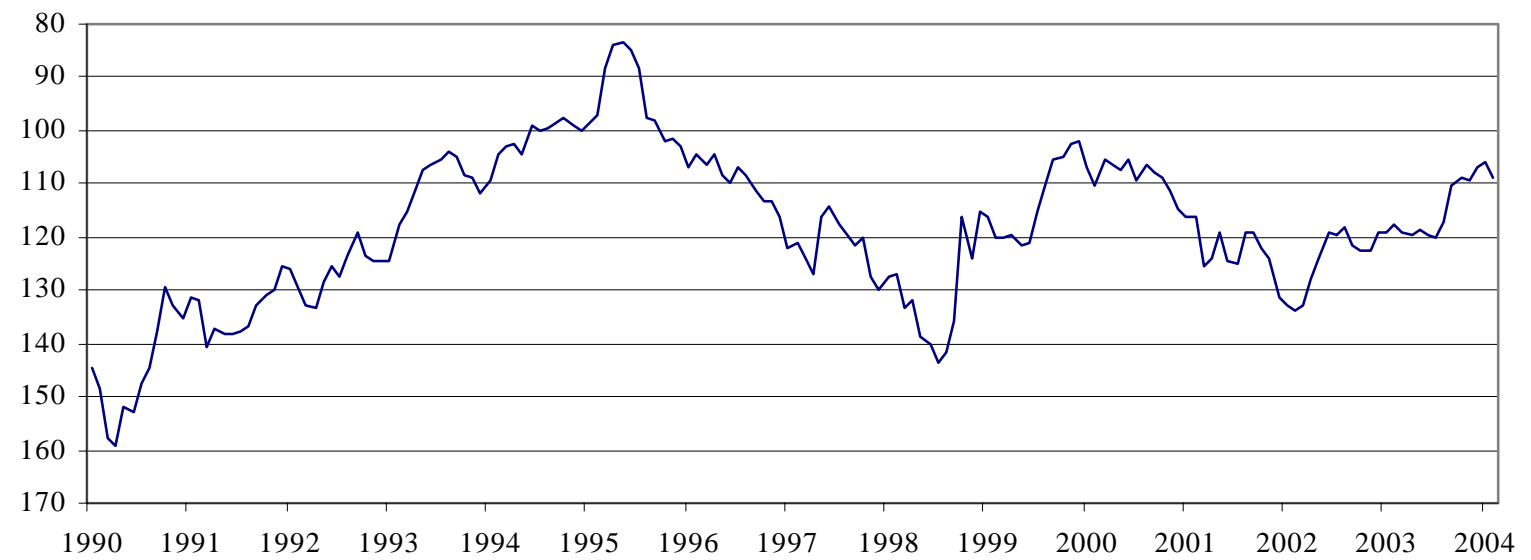

Source: Bank of Japan. Online: http://www2.boj.or.jp/en/dlong/stat/data/cdab0780.txt

\section{Figure 9: Bankruptcies}

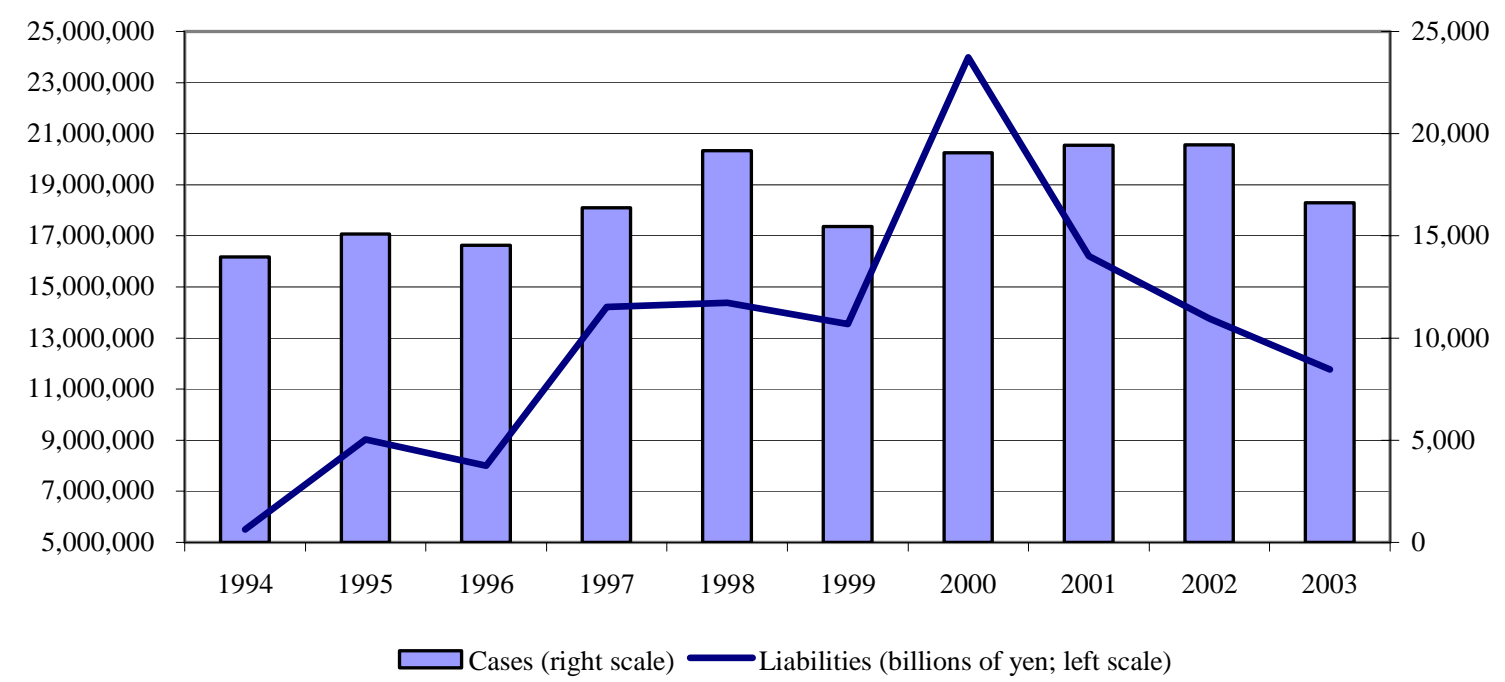

Source: Teikoku Databank. 
Figure 10: Inward FDI flows: world and Japan (million US\$)

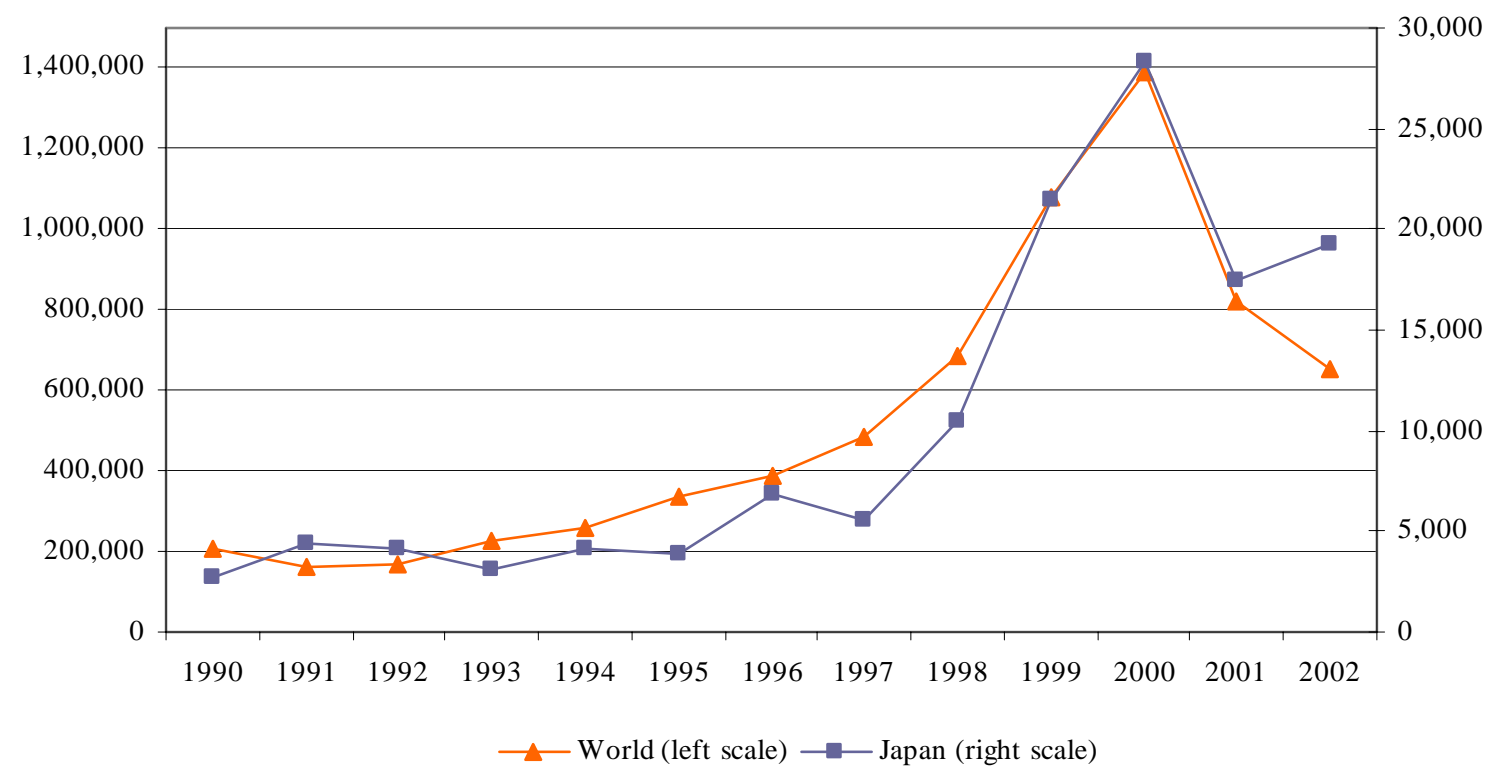

Sources: UNCTAD; JETRO (see figure 1).

Figure 11: Japan's share in global inward FDI flows ( percent)

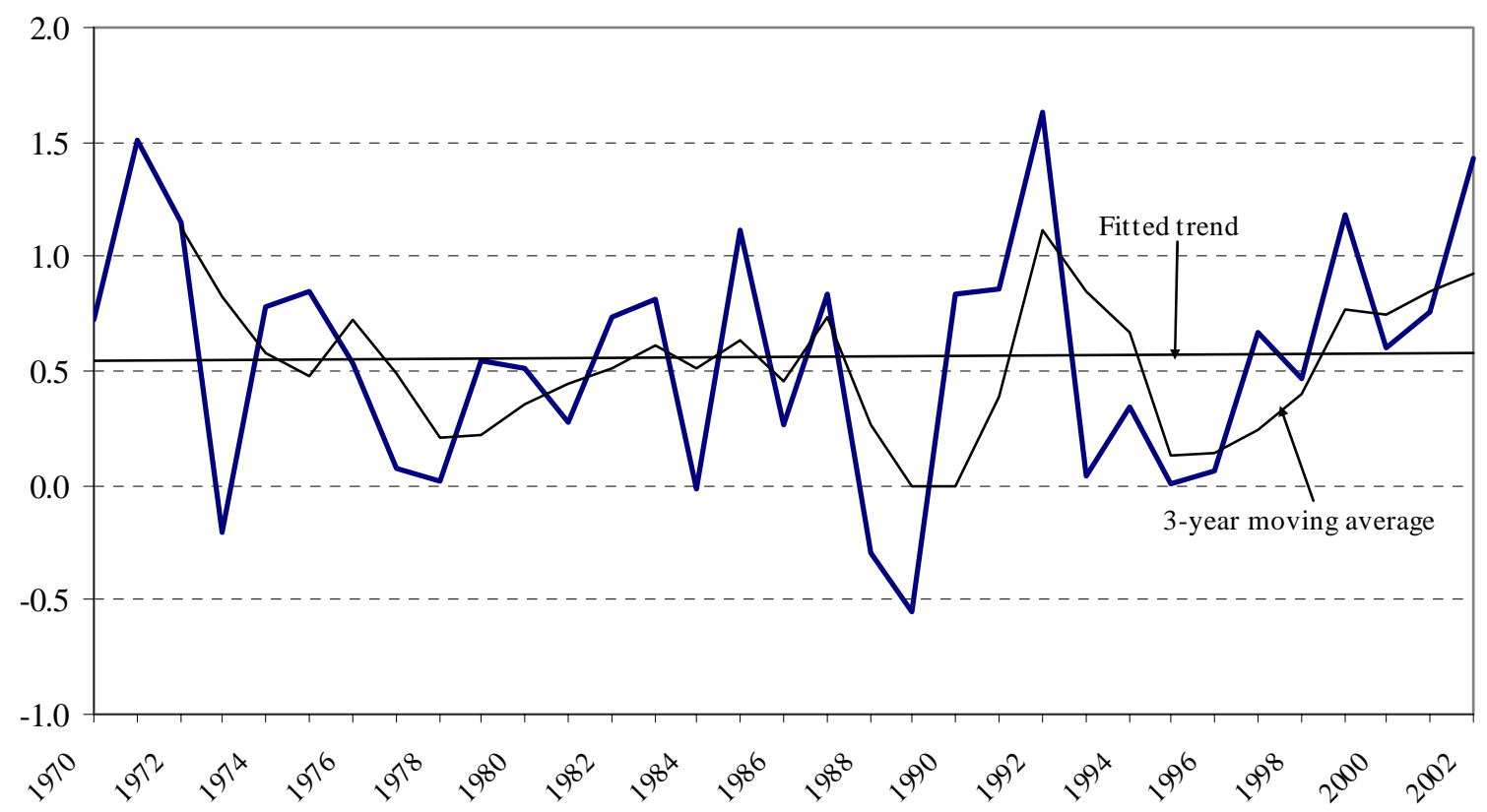

Source: Author's calculations based on UNCTAD. 
Figure 12: Japanese inward FDI and global M\&As by sector, 1995-1997 and 1998-2000
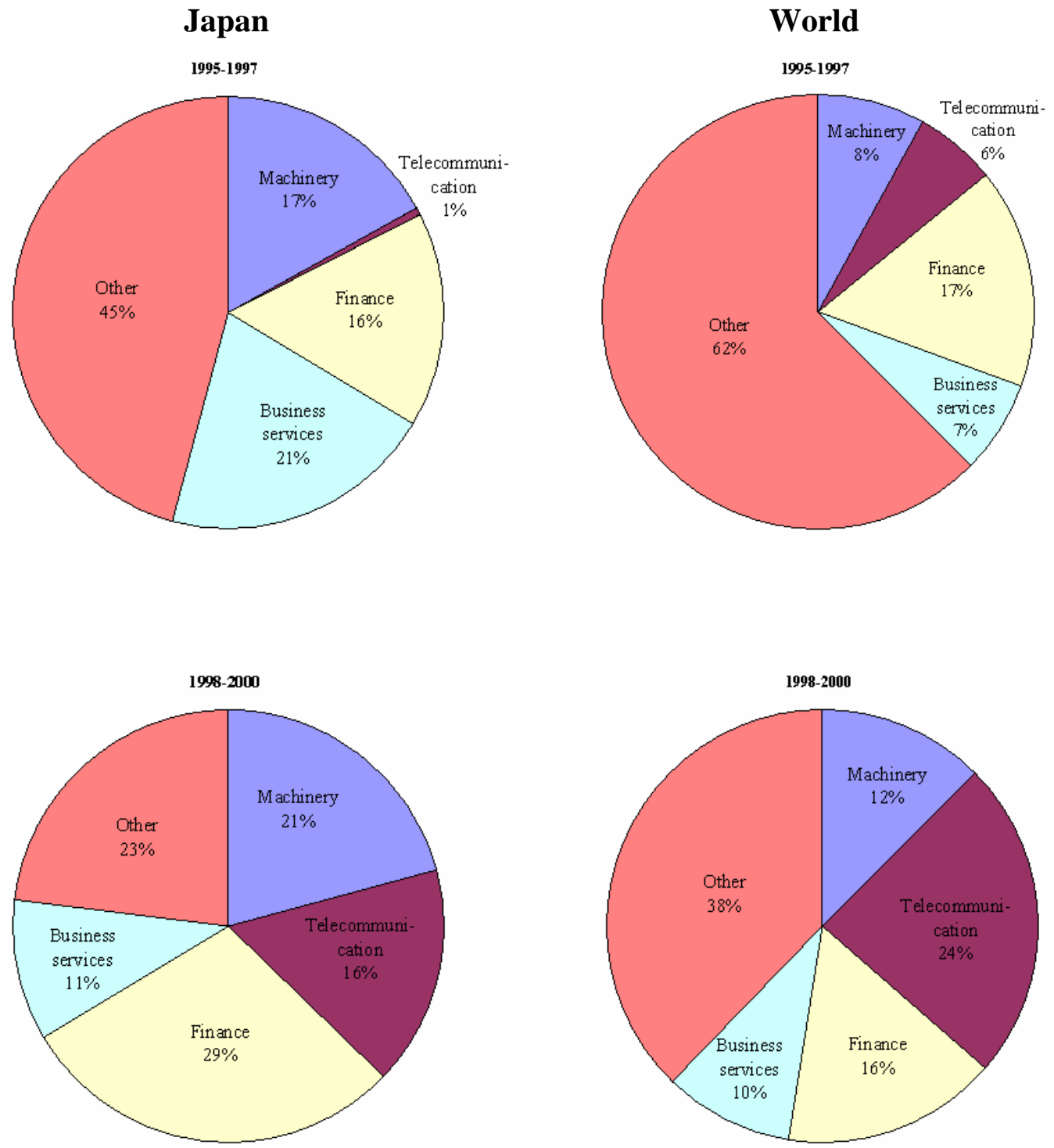

Sources: MOF; UNCTAD. 
Figure 13: Comparison of global M\&As (left scale) and Japanese inward FDI flows (right scale) (million US\$)

\section{Telecommunication}

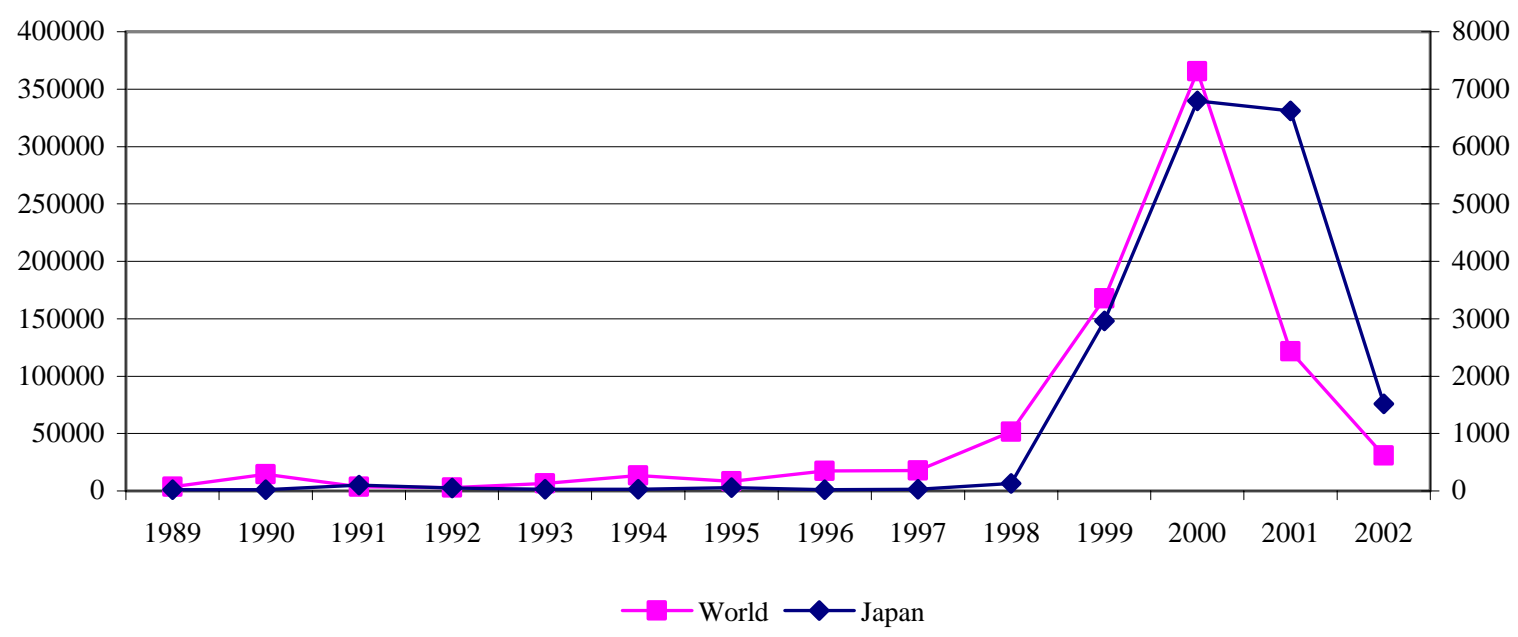

\section{Finance}

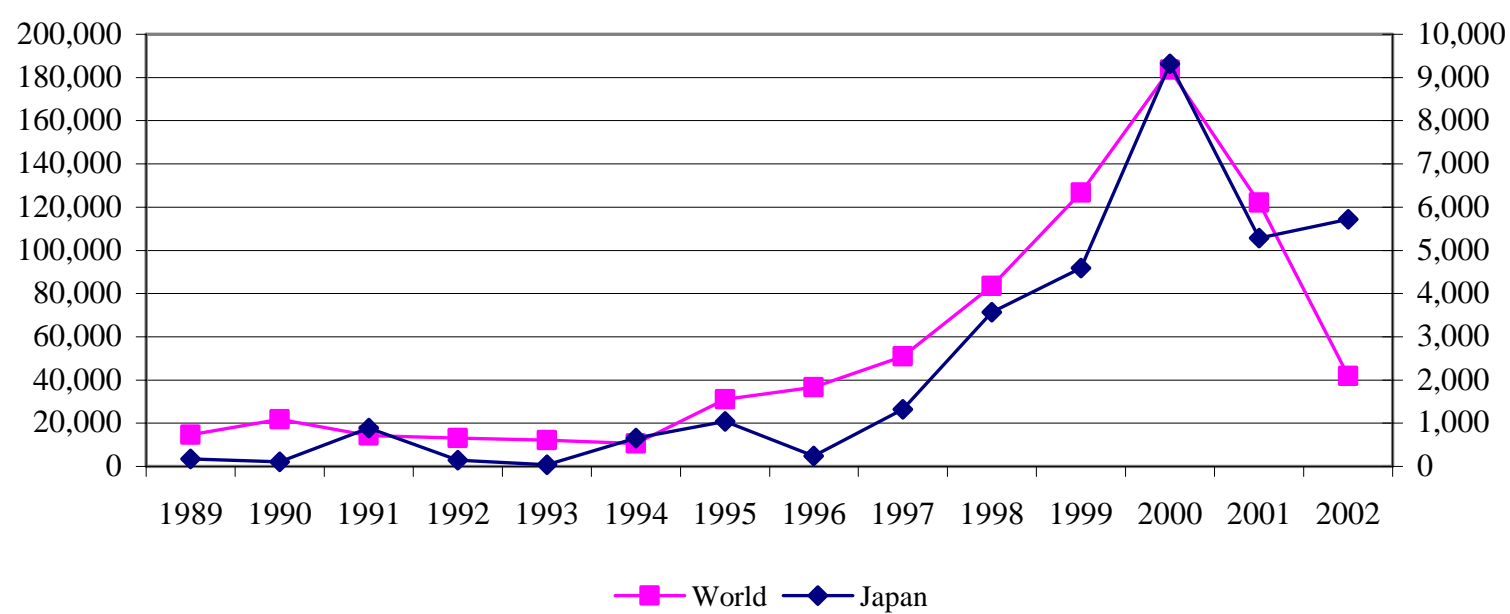

Machinery

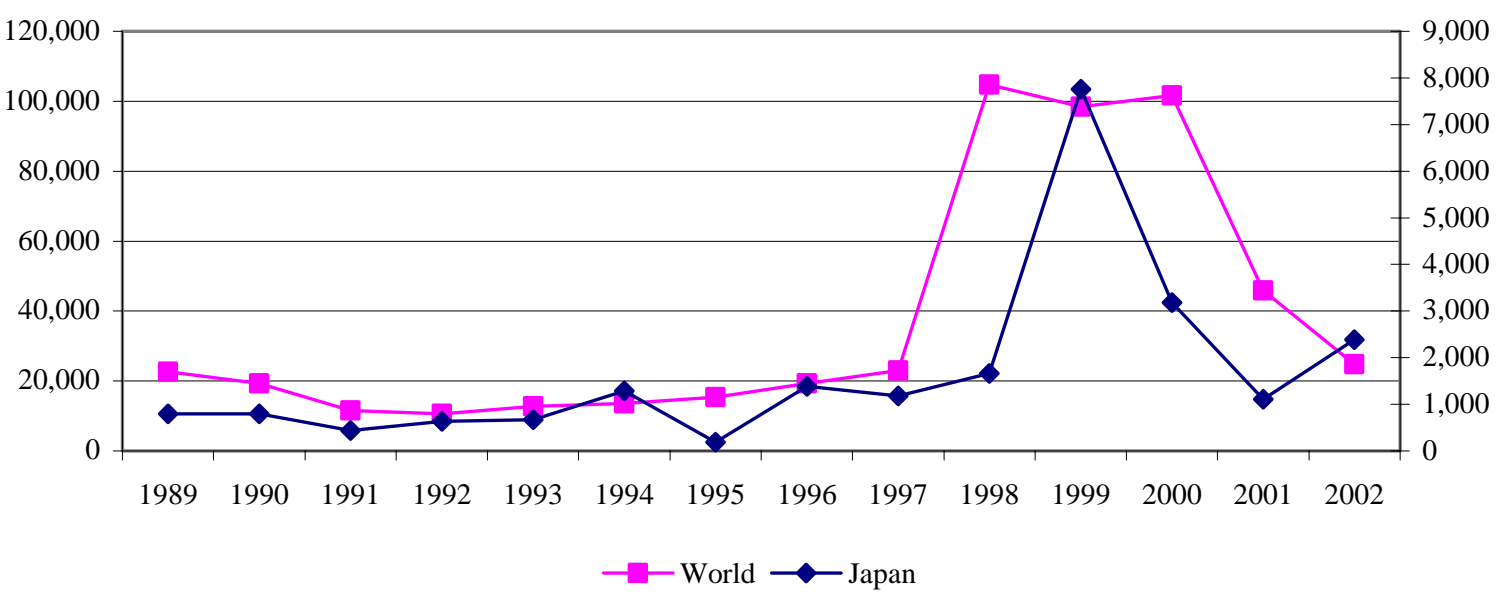




\section{Business services}

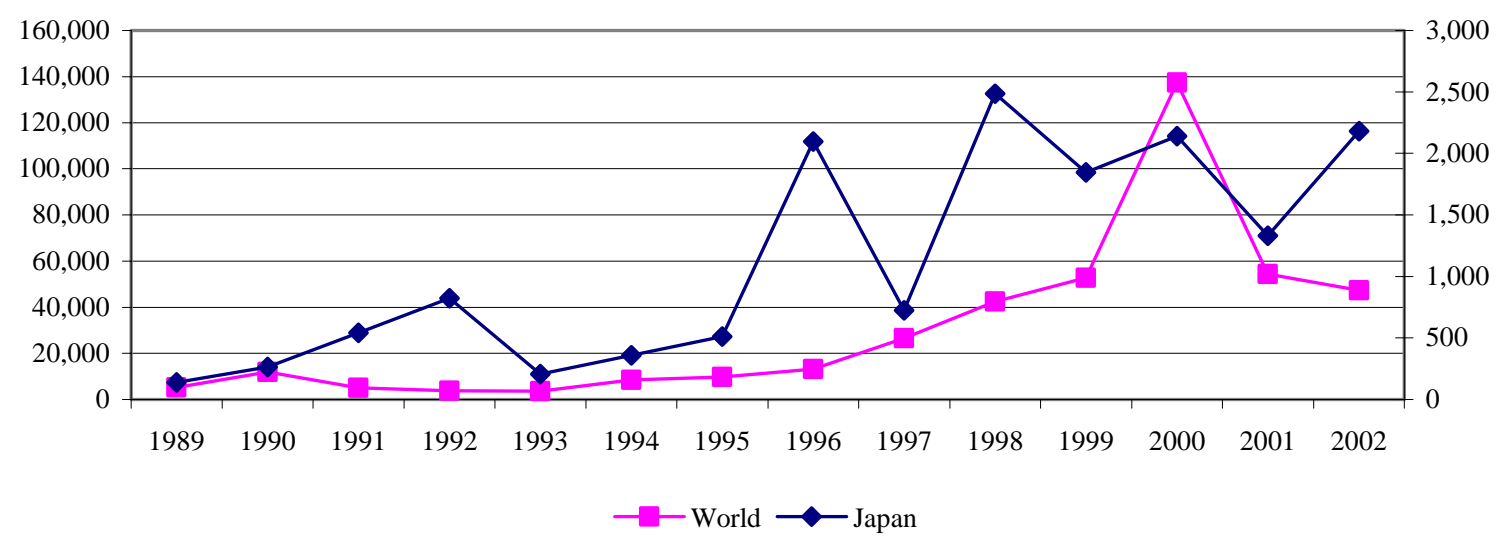

\section{Trade}

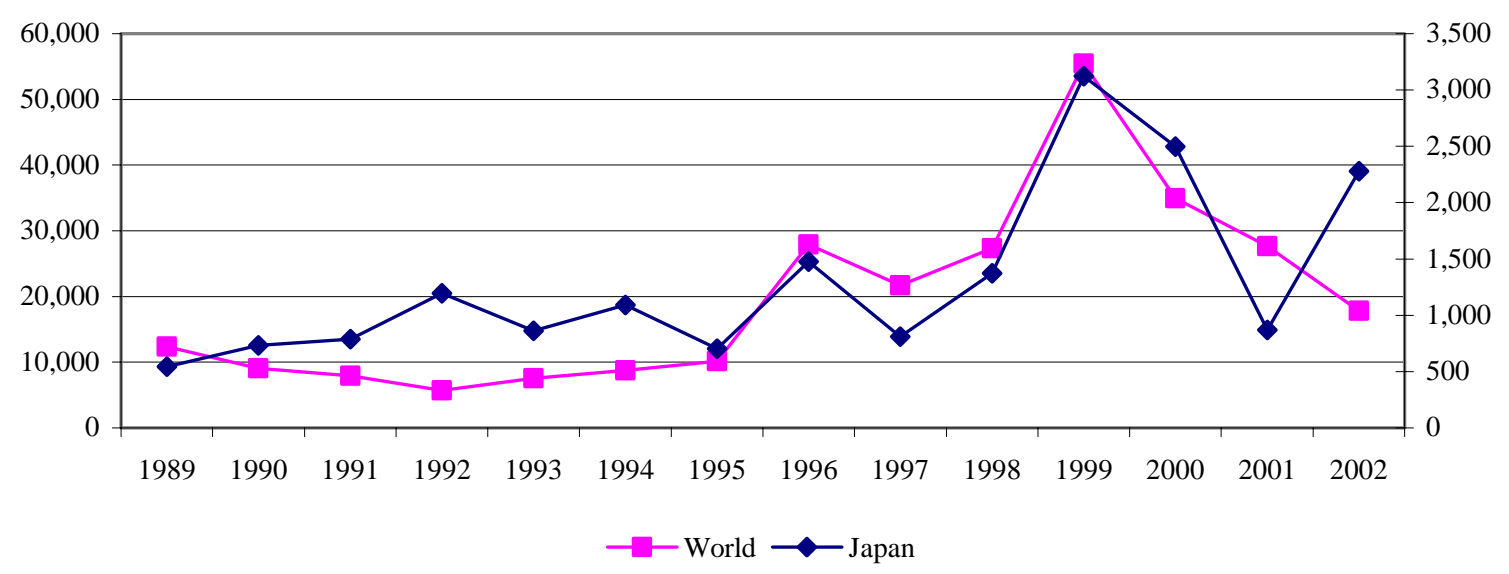

\section{Chemical}

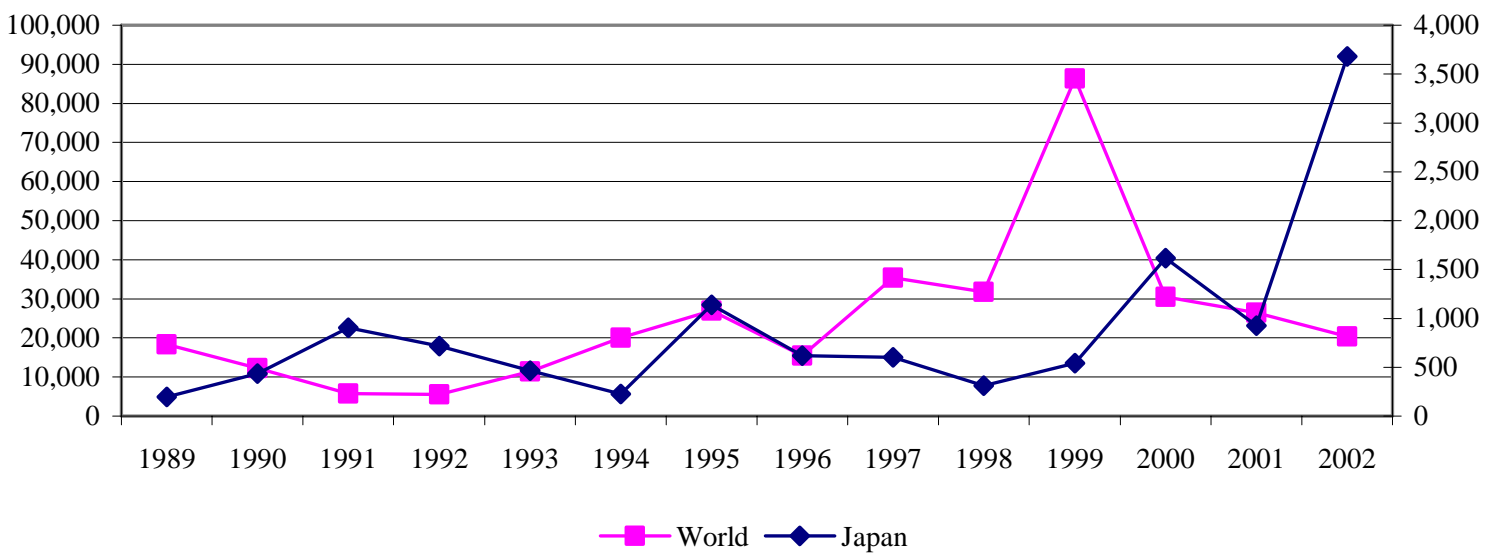

Sources: UNCTAD; MOF.

Note: MOF data are on a notification basis. Sectoral flows were converted into US\$ using the average annual interbank exchange rate. 
Figure 14: Japanese FDI inflows on a notification and BOP basis (billion yen)

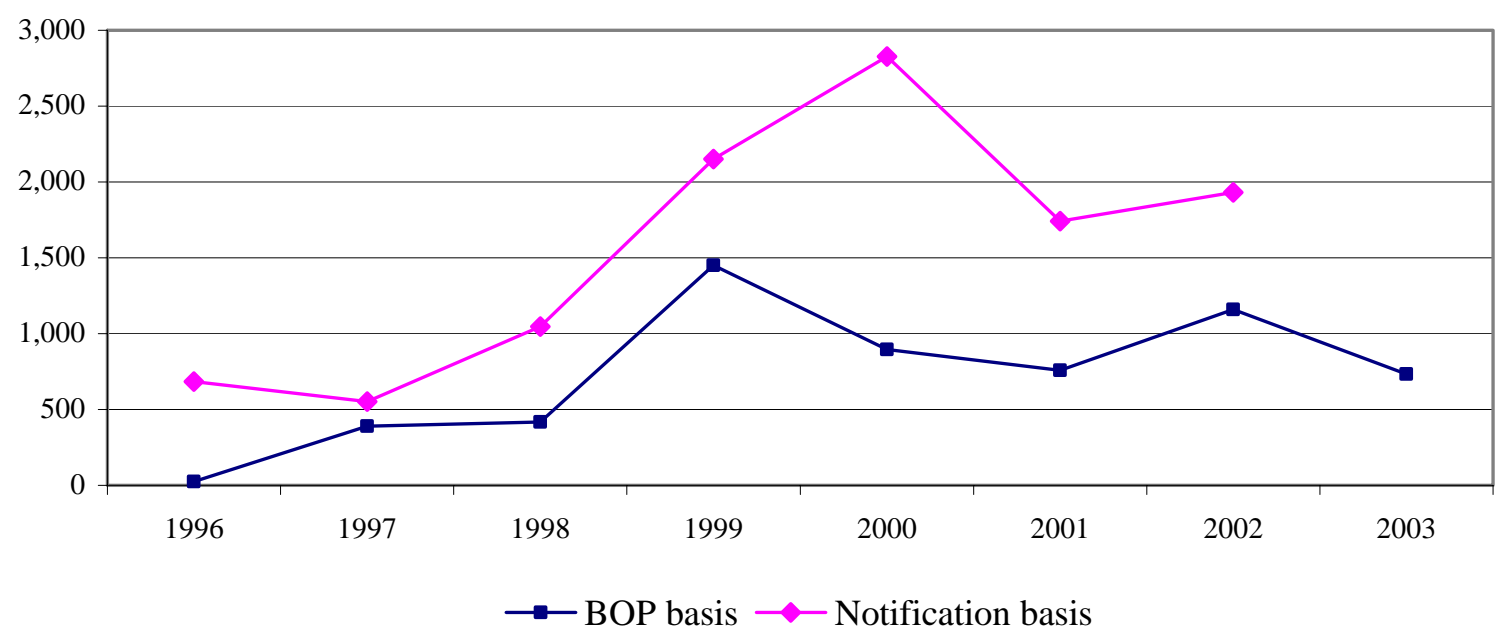

Note: It should be noted that notification data are on a fiscal year basis, while BOP data here were calculated on a calendar year basis.

Sources: Ministry of Finance; Bank of Japan. 
Table 1: Distribution of inward FDI in Japan (in percent)

\begin{tabular}{lrrr}
\hline & $1989-95$ & $1996-2002$ & $1989-2002$ \\
\hline Food & 1.4 & 0.6 & 0.7 \\
Textile & 0.2 & 0.1 & 0.1 \\
Rubber and leather & 1.1 & 0.4 & 0.5 \\
Chemical & 16.1 & 7.5 & 9.2 \\
Metal & 2.6 & 0.7 & 1.1 \\
Machinery & 19.4 & 16.9 & 17.4 \\
Petroleum & 1.9 & 2.8 & 2.6 \\
Glass and ceramics & 0.2 & 0.1 & 0.1 \\
Other manufacturing & 2.1 & 0.9 & 1.1 \\
\hline Manufacturing total & 44.9 & 30.1 & 33.0 \\
\hline Telecommunication & 1.2 & 16.6 & 13.6 \\
Construction & 0.2 & 0.1 & 0.1 \\
Trading & 23.6 & 11.3 & 13.7 \\
Finance and insurance & 11.4 & 27.6 & 24.4 \\
Service & 11.3 & 11.8 & 11.7 \\
Transportation & 0.7 & 0.2 & 0.3 \\
Real Estate & 4.9 & 2.1 & 2.7 \\
Other & 1.7 & 0.2 & 0.5 \\
\hline Non-manufacturing total & 55.1 & 69.9 & 67.0 \\
\hline TOTAL & $\mathbf{1 0 0}$ & $\mathbf{1 0 0}$ & $\mathbf{1 0 0}$ \\
\hline Source Authos calculations & & &
\end{tabular}

Source: Author's calculations based on MOF.

Table 2: Comparison of FDI in Japan, the United States and China

Japan United States China

Share in global FDI flows

$\begin{array}{llll}1981-1985 & 0.6 & 32.4 & 1.4 \\ 1986-1990 & 0.2 & 34.3 & 1.8 \\ 1991-1995 & 0.4 & 17.2 & 9.9 \\ 1996-2000 & 0.7 & 23.8 & 5.2\end{array}$

Share in global FDI stocks

\begin{tabular}{cccc}
1980 & 0.5 & 11.9 & 0.9 \\
1985 & 0.5 & 18.9 & 1.1 \\
1990 & 0.5 & 20.2 & 1.3 \\
1995 & 1.1 & 17.8 & 4.6 \\
2000 & 0.8 & 19.8 & 5.7 \\
2001 & 0.8 & 20.0 & 6.0 \\
2002 & 0.8 & 19.0 & 6.3 \\
\hline Source: Author's calculations based on UNCTAD
\end{tabular}

Source: Author's calculations based on UNCTAD. 